\title{
水田土袞中ダイオキシン類の起源と推移
}

\author{
清家 伸康 ${ }^{1)}$, 大谷 卓 ${ }^{1)}$, 上路 雅子 ${ }^{1)}$, 高菅 卓三 ${ }^{2)}$, 都築 伸幸 ${ }^{3)}$ \\ 1)独立行政法人農業環境技術研究所（テ305-8604 茨城県つくば市観音台3-1-3） \\ 2)(侏)島津テクノリサーチ（テ604-8436＼cjkstart京都市中京区西ノ京下合町 1) \\ 3)農林水産省生産局（テ100-8950 東京都千代田区霞が関1-2-1）
}

[平成14年10月 1 日受理］

\section{Temporal Change of Polychlorinated Dibenzo-p-Dioxins, Dibenzofurans and Dioxin Like Polychlorinated Biphenyls Source in Paddy Soils}

\author{
Nobuyasu SEIKE ${ }^{1)}$, Takashi OTANI ${ }^{1}$, Masako UEJI ${ }^{1}$, \\ Takumi TAKASUGA ${ }^{2)}$ and Nobuyuki TSUZUKI ${ }^{3)}$ \\ ${ }^{1)}$ National Institute for Agro-Environmental Sciences \\ (3-1-3 Kannondai, Tsukuba, Ibaraki 305-8604) \\ ${ }^{2)}$ Shimazu Techno-Research Inc. \\ (1 Nishinokyo-Shimoaicho, Nakagyo-ku, Kyoto 604-8436) \\ ${ }^{3)}$ The Ministry of Agriculture, Forestry and Fisheries of Japan \\ (1-2-1 Kasumigaseki, Chiyoda-ku, Tokyo 100-8950)
}

[Received October 1, 2002]

\begin{abstract}
Summary
Polychlorinated dibenzo- $p$-dioxins, dibenzofurans (PCDD/Fs) and dioxin like polychlorinated biphenyls (Co-PCBs) in agrochemical formulations, such as PCP and CNP, and paddy soils collected and preserved from 1960 were investigated. Different concentrations and compositions of $\mathrm{PCDD} / \mathrm{Fs}$ in PCP could be found between synthesized by chlorination of phenol and hydroxylation of hexachlorobenzene. We calculated PCDD/Fs emission from PCP and CNP from 1958 to 1994. It was expected that PCDD/Fs emission from PCP was increased from early 1960s, then, rapidly reduced from early 1970s. On the other hand, that from CNP was increased from the latter half of 1960 s instead of PCP.

Concentration of PCDD/Fs and TEQ in paddy soils was increased during 1960s $\sim 1970$ s. Then the contamination has been reduced in recent years. It can be observed that transition of OCDD and 1,3,6,8-TeCDD concentrations and circulation of PCP and CNP were well agreed. Principal component analysis was applied to 2,3,7,8-substituted congener contributions to TEQ to evaluate the time trends of $\mathrm{PCDD} / \mathrm{Fs}$ sources in paddy soils. It was thought that contribution to TEQ by 2,3,7,8-substituted congeners originated from PCP and CNP were reduced, however, that from combustion process was gradually increased in recent 20 years.
\end{abstract}

Key words: PCDDs, PCDFs, Paddy Soil, PCP, CNP 


\section{1.はじめに}

ダイオキシン 類〔Polychlorinated dibenzo-p-dioxins (PCDDs), Polychlorinated dibenzofurans (PCDFs), 及 び Dioxin like polychlorinated biphenyl ( $\mathrm{Co}-\mathrm{PCBs})$, $\mathrm{PCDDs}+\mathrm{PCDFs}$ の場合は PCDD/Fs と略記〕の主な起源 として, 燃焼・焼却過程”が挙げられる。さらに Polychlorinated biphenyl (PCBs) ${ }^{2-4)}$ や有機塩素系農薬(5-12) といった化学製品の製造過程が考えられている。燃焼 . 焼却過程で生成する PCDD/Fsには全異性体が含まれる。 一方, 絶縁体等として使用された $\mathrm{PCBs}^{2-4}$ からは, 主に PCDFs が検出され, PCDDs は不検出あるいは極微量し か検出されない。また, 2,4,5-trichlorophenoxy acetic acid（2，4, 5-T) 及びその誘導体 ${ }^{6}$ では主として2,3,7, 8TeCDD が, Pentachlorophenol (PCP $)^{10.11}$ では主に $\mathrm{OCDD} / \mathrm{F}$ や $\mathrm{HpCDD} / \mathrm{Fs}$ といった塩素数が多い異性体が検 出される。そして1,3,5-trichloro-2-( 4-nitrophenoxy) benzene $(\mathrm{CNP})^{11,12)}$ では主に1,3, 6, 8-TeCDD や1,3, 7, 9$\mathrm{TeCDD}$ といった塩素数の少ない異性体が不純物として 含まれていた。このように PCDD/Fs の組成はその起源 毎に特徴的であり，これを利用して環境試料の起源推定 を行うことが可能である。

我が国の水田では，PCP および CNP 製剤が除草剛と して使用された。Fig. 1 に両製凨の出荷量に含有率を乗 じた原体としての出荷量の推移 ${ }^{13)}$ を示した。PCP 製剂は 1960年頃から使用が開始されたが，魚介類に対する毒性 回避のため, 1970年代前半に水田への使用が急減し, 1990年に農薬登録が失効した。CNP製剤は1960年代後半 から PCP 製剂に代わって使用されるようになったが, 1996年に農薬登録が失効した。しかし，河川，湖沼およ び沿岸底質中の PCDD/Fsは, 過去に水田で使用された
PCP およびCNP製剤中の不純物として含まれる $\mathrm{PCDD} / \mathrm{Fs}$ が影響していることが指摘されている ${ }^{14-16)}$ 。 従って, 過去の水田土壤中のダイオキシン類を分析する ことは, 過去の污染状況の把握，拈よび将来予測を行う 上で重要であると考えられる。

そこで，本報では PCP および CNP 製剤中のダイオキ シン類を分析し，含有濃度と組成を明らかにし，両製剤 から排出されたダイオキシン類量を算出し，これを基に 水田土壤中ダイオキシン類濃度を試算した。一方， 1960 年から農業環境技術研究所に保存されている水田土壤中 $\mathrm{PCDD} / \mathrm{Fs}$ を分析し, 濃度及び組成の推移について検討 を行い，水田土壤中ダイオキシン類に対するPCP およ びCNP 製片の影響について解析した。

\section{2. 実験方法}

\section{1 試料}

1966年から1985年製造と推定される PCP 製剂10検体, 1972年から1994年製造と推定される CNP 製剤24検体を 分析試料とした。

水田土壤試料は，1960年以後毎年同一圈場で採取され たものである。これらの試料は, 風乾・篩別後, 二重栓 付きのポリエチレン瓶に暗所保存されていた。分析試料 は1960年以後 3 年おきの計14検体とした。なお，ポリ工 チレン瓶から試料を取り出す際に, 開封によるコンタミ ネーションを考慮して，表層部を除去した。

\section{2 ダイオキシン類の分析法}

2. 2. 1 抽出及びクリーンアップ

PCP およびCNP 製剤中ダイオキシン類の抽出は, 剤 型により異なる方法を用いた。粒剤と水和郕はジクロロ メタンによるソックスレー抽出, 乳骹はジクロロメタン

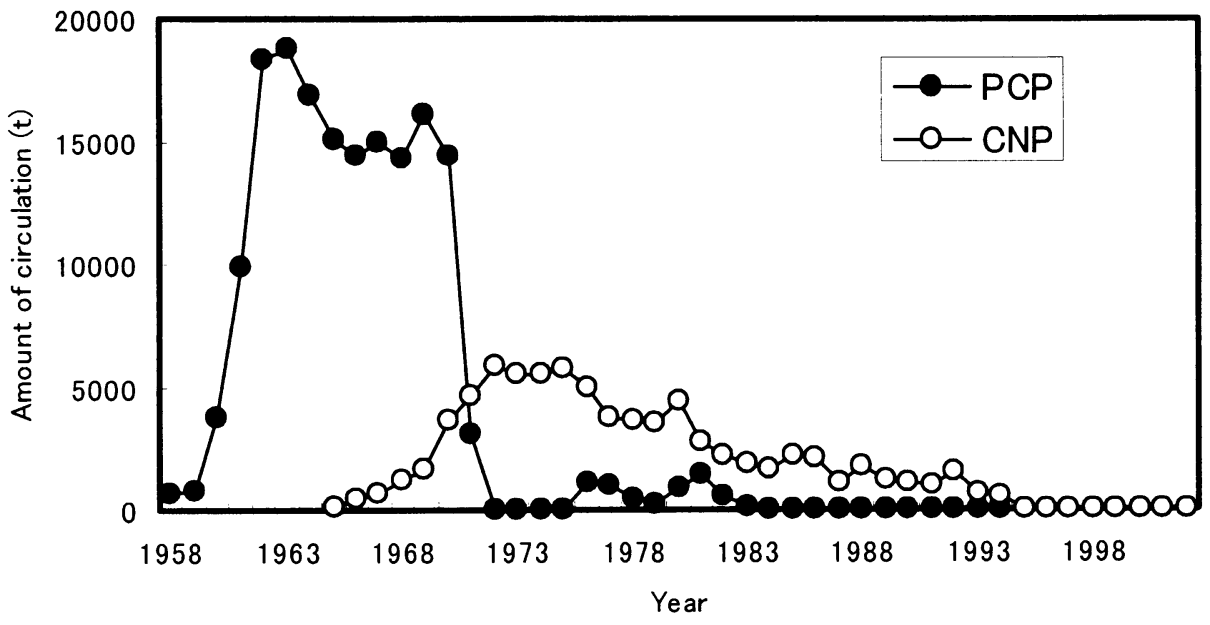

Fig. 1 Temporal change of PCP and CNP shipment ${ }^{13)}$ in Japan 
による振とう抽出を行い, 原体についてはジクロロメ タンに溶解し, これらを粗抽出液とした。粗抽出液に 内部標準物質として ${ }^{13} \mathrm{C}-2,3,7,8-\mathrm{TeCDD}$ と 17 種の ${ }^{13} \mathrm{C}-$ 2,3,7,8- 位塩素置換 PCDD/Fs (Wellington Laboratories 製) 及び14種 ${ }^{13} \mathrm{C}-\mathrm{Co}-\mathrm{PCBs}$ (Wellington Laboratories 製）を添加した。クリーンアップは，過去の報告例10-12) から両製剤中 PCDD/Fs は異性体により濃度が大きく異 なることが予想されたため, 高濃度の異性体およびその 他の異性体分析用に分けて行った ${ }^{17)}$ 。PCP 製剤の場合, 高濃度の異性体分析のクリーンアップではシリカゲルカ ラムを, その他の異性体分析ではシリカゲルカラムを 2,3 回, さらにアルミナカラムと活性炭カラムを用い た。CNP 製剤の場合, 高濃度の異性体分析ではシリカゲ ルカラムを, その他の異性体分析ではシリカゲルカラム を $2 \sim 3$ 回, アルミナカラムを 2 回, クリーンアップと して順次用いた。その後, シリンジスパイク $\left({ }^{13} \mathrm{C}-\right.$ PCDD/Fs おょ び'13 C-Co-PCBs, Wellington Laboratories 製）を添加し， GC/MS 測定用試料とした。

土壤試料は, トルエンで24時間ソックスレー抽出し
た。粗抽出液に内部標準物質として 17 種の ${ }^{13} \mathrm{C}-2,3,7,8^{-}$ 位塩素置換 PCDD/Fs (Wellington Laboratories 製) 及び 14種の ${ }^{13} \mathrm{C}-\mathrm{Co}-\mathrm{PCBs}$ (Wellington Laboratories 製)を添加 した。その後硫酸処理, 多層シリカゲルカラム（硝酸銀 シリカゲル, 硫酸シリカゲル, $\mathrm{KOH}$ シリカゲル), 活性 炭カラムによるクリーンアップを行った。その後, シリ ンジスパイク $\left({ }^{13} \mathrm{C}-\mathrm{PCDD} / \mathrm{Fs}\right.$ お $ひ ゙{ }^{13} \mathrm{C}-\mathrm{Co}-\mathrm{PCBs}$, Wellington Laboratories 製) を添加し， GC/MS 測定用試 料とした。

\section{2 . $2 \mathrm{GC} / \mathrm{MS}$ 測定および同定・定量}

ダイオキシン類の測定は HRGC-HRMS（HP6890AutoSpec-Ultima Micromass 製と HP6890-JMS700 日本 電子製) を用いSIM 法で行った。分析条件を Table 1 と Table 2 に示した。なお, 農薬製剤の分析においては, 2,3,7,8-位塩素置換の異性体について妨害の疑いの可 能性がある試料については $2 \sim 3$ 種の GC カラムにより 定量值の確認分析を行なった。従って 1 試料につき $\mathrm{PCDD} / \mathrm{Fs}$ については $3 \sim 4$ 回の注入を行った。

同定は, 2,3,7,8-位塩素置換 PCDD/Fs と Co-PCBsに

Table 1 Operational conditions of HRGC/HRMS for PCDD/Fs analysis

\begin{tabular}{|c|c|c|c|c|}
\hline GC/MS & \multicolumn{4}{|c|}{ HP6890(Hewlett-Packard)/ AutoSpec Ultima(Micromass) } \\
\hline \multicolumn{5}{|c|}{$\cdots$ GC Conditions $\cdots$} \\
\hline Column & \multicolumn{4}{|c|}{ SP-2331 $(0.32 \mathrm{~mm}$ i.d. $\times 60 \mathrm{~m}, 0.20 \mu \mathrm{m})$} \\
\hline \multirow[t]{2}{*}{ Oven Temp. } & \multicolumn{4}{|c|}{$160^{\circ} \mathrm{C}, 1 \mathrm{~min}-6^{\circ} \mathrm{C} / \mathrm{min} \rightarrow 200^{\circ} \mathrm{C}-3^{\circ} \mathrm{C} / \mathrm{min} \rightarrow 260^{\circ} \mathrm{C}, 30 \mathrm{~min}$} \\
\hline & \multicolumn{4}{|c|}{$170^{\circ} \mathrm{C}, 1 \mathrm{~min}-20^{\circ} \mathrm{C} / \min \rightarrow 210^{\circ} \mathrm{C}-2^{\circ} \mathrm{C} / \min \rightarrow 255^{\circ} \mathrm{C}, 30 \mathrm{~min}$} \\
\hline Column & \multicolumn{4}{|c|}{ DB-17HT $(0.32 \mathrm{~mm}$ i.d. $\times 60 \mathrm{~m}, 0.15 \mu \mathrm{m})$} \\
\hline Oven Temp. & \multicolumn{4}{|c|}{$130^{\circ} \mathrm{C}, 1 \mathrm{~min}-30^{\circ} \mathrm{C} / \mathrm{min} \rightarrow 200^{\circ} \mathrm{C}-4^{\circ} \mathrm{C} / \min \rightarrow 300^{\circ} \mathrm{C}, 5 \min$} \\
\hline Column & \multicolumn{4}{|c|}{ DB-5 $(0.25 \mathrm{~mm}$ i.d. $\times 60 \mathrm{~m}, 0.25 \mu \mathrm{m})$} \\
\hline Oven Temp. & \multicolumn{4}{|c|}{$130^{\circ} \mathrm{C}, 1 \mathrm{~min}-30^{\circ} \mathrm{C} / \min \rightarrow 200^{\circ} \mathrm{C}-4^{\circ} \mathrm{C} / \mathrm{min} \rightarrow 240^{\circ} \mathrm{C}-6^{\circ} \mathrm{C} / \min 300^{\circ} \mathrm{C}, 15 \mathrm{~min}$} \\
\hline & \multicolumn{4}{|c|}{$160^{\circ} \mathrm{C}, 1 \mathrm{~min}-20^{\circ} \mathrm{C} / \min \rightarrow 200^{\circ} \mathrm{C}-5^{\circ} \mathrm{C} / \min \rightarrow 240^{\circ} \mathrm{C}-2.5^{\circ} \mathrm{C} / \min 280^{\circ} \mathrm{C}, 22.5 \mathrm{~min}$} \\
\hline \multicolumn{5}{|c|}{$\cdots$ MS Conditions $\cdots$} \\
\hline Resolution & \multicolumn{4}{|l|}{10000} \\
\hline Ionizing Current & \multicolumn{4}{|l|}{$500 \mu \mathrm{A}$} \\
\hline Ionizing Voltage & \multicolumn{4}{|l|}{$35-40 \mathrm{eV}$} \\
\hline Ion Source Temp. & \multicolumn{4}{|l|}{$290^{\circ} \mathrm{C}$} \\
\hline Accel. Voltage & \multicolumn{4}{|l|}{$8 \mathrm{kV}$} \\
\hline \multirow[t]{11}{*}{ Monitor Ions } & \multicolumn{2}{|l|}{${ }^{12} \mathrm{C}$} & \multicolumn{2}{|l|}{${ }^{13} \mathrm{C}$} \\
\hline & TeCDDs & $319.8965,321.8937$ & TeCDDs & $331.9368,333.9339$ \\
\hline & PeCDDs & $353.8576,355.8547,357.8516$ & PeCDDs & $365.8978,367.8949,369.8919$ \\
\hline & HxCDDs & $389.8157,391.8128$ & HxCDDs & $401.8559,403.8530$ \\
\hline & HpCDDs & $423.7767,425.7738$ & HpCDDs & $435.8169,437.8140$ \\
\hline & OCDD & $457.7377,459.7348$ & OCDD & $469.7779,471.7750$ \\
\hline & TeCDFs & $303.9016,305.8987$ & TeCDFs & $315.9419,317.9389$ \\
\hline & PeCDFs & $337.8627,339.8598$ & PeCDFs & $349.9029,351.9000$ \\
\hline & HxCDFs & $373.8208,375.8179$ & $\mathrm{HxCDFs}$ & $385.8610,387.8581$ \\
\hline & HpCDFs & $407.7818,409.7789$ & HpCDFs & $419.8220,421.8191$ \\
\hline & OCDF & $441.7428,443.7399$ & OCDF & $453.7830,455.7801$ \\
\hline
\end{tabular}


Table 2 Operational conditions of HRGC/HRMS for Co-PCBs analysis

\begin{tabular}{|c|c|c|c|c|}
\hline GC/MS & \multicolumn{4}{|c|}{$\begin{array}{l}\text { HP6890 (Hewlett-Packard) / JMS-700(JEOL) or } \\
\text { HP6890(Hewlett-Packard) / AutoSpec Ultima(Micromass) }\end{array}$} \\
\hline \multicolumn{5}{|c|}{$\cdots$ GC Conditions $\cdots$} \\
\hline Column & \multicolumn{4}{|c|}{ DB $-5 \mathrm{MS}(0.25 \mathrm{~mm}$ i.d. $\times 60 \mathrm{~m}, 0.25 \mu \mathrm{m})$} \\
\hline \multirow{2}{*}{ Oven Temp. } & \multicolumn{4}{|c|}{$150^{\circ} \mathrm{C}, 1 \mathrm{~min}-20^{\circ} \mathrm{C} / \mathrm{min} \rightarrow 185^{\circ} \mathrm{C}-2^{\circ} \mathrm{C} / \mathrm{min} \rightarrow 245^{\circ} \mathrm{C}-6^{\circ} \mathrm{C} / \mathrm{min} \rightarrow 290^{\circ} \mathrm{C}, 14 \mathrm{~min}$} \\
\hline & \multicolumn{4}{|c|}{$160^{\circ} \mathrm{C}, 1 \min -20^{\circ} \mathrm{C} / \min \rightarrow 200^{\circ} \mathrm{C}-5^{\circ} \mathrm{C} / \min \rightarrow 240^{\circ} \mathrm{C}-2.5^{\circ} \mathrm{C} / \min 280^{\circ} \mathrm{C}, 22.5 \min$} \\
\hline \multicolumn{5}{|c|}{$\cdots$ MS Conditions $\cdots$} \\
\hline Resolution & \multicolumn{4}{|l|}{10000} \\
\hline Ionizing Current & \multicolumn{4}{|l|}{$500 \mu \mathrm{A}$} \\
\hline Ionizing Voltage & \multicolumn{4}{|l|}{$40 \mathrm{eV}$} \\
\hline Ion Source Temp. & \multicolumn{4}{|l|}{$290^{\circ} \mathrm{C}$} \\
\hline Accel. Voltage & \multicolumn{4}{|l|}{$8 \mathrm{kV}$} \\
\hline \multirow[t]{5}{*}{ Monitor Ions } & \multicolumn{2}{|l|}{${ }^{12} \mathrm{C}$} & \multicolumn{2}{|l|}{${ }^{13} \mathrm{C}$} \\
\hline & TeCBs & $289.9224,291.9194$ & TeCBs & $301.9626,303.9597$ \\
\hline & $\mathrm{PeCBs}$ & $325.8804,327.8775$ & $\mathrm{PeCBs}$ & $337.9207,339.9178$ \\
\hline & $\mathrm{HxCBs}$ & $359.8415,361.8385$ & $\mathrm{HxCBs}$ & $371.8817,373.8788$ \\
\hline & HpCBs & $393.8025,395.7995$ & $\mathrm{HpCBs}$ & $405.8428,407.8398$ \\
\hline
\end{tabular}

ついては定量用標準物質及び13 C でラベルされた標準物 質の保持時間から行い, 2,3, 7,8-位塩素置換 PCDD/Fs 以外の異性体は Ryan ( $^{18)}$ による相対保持時間及び飛扊 抽出物中の PCDD/Fs 保持時間から推定した。

定量は, 2,3, 7, 8- 位塩素置換 PCDD/Fs とCo-PCBsに ついては定量用標準物質毎に相対感度係数を求め, 内部 標準との相対感度比から濃度を算出した。2,3,7,8-位塩 素置換 $\mathrm{PCDD} / \mathrm{Fs}$ 以外の異性体は, 同じ塩素数の $2,3,7,8$ - 位塩素置換 PCDD/Fs の相対感度比 (PeCDFs, $\mathrm{HxCDDs}, \mathrm{HxCDFs}$ および $\mathrm{HpCDFs}$ の場合は平均値）か ら濃度を算出した。

なお考察には, Table $3 に$ 示した農薬中ダイオキシン 類の検査基準値 ${ }^{19}$ 以上の測定値を用いた。

\section{3. 結果と考察}

\section{1 PCP と CNP 製剤中ダイオキシン類について}

3. 1 . 1 PCP 製剤中ダイオキシン類濃度と組成

Table 4 に各製剂中ダイオキシン類の分析結果を示し た。これらの濃度は原体あたりに換算した值である。な お2, 3, 7,8-TeCDD 毒性当量（TEQ）は WHO-TEF ${ }^{200}$ を 用いて算出した。また，推定製造年，剤型（粒剤，乳剂， 水溶剂, 原体) およびPCPの製造方法も併せて示してい る。なお製造年は各製剤の最終有効年限から推定した。 すなわち, 最終有効年限から有効年限（3 年）を差し引 きこれを製造年とした。

PCP 製剂中のダイオキシン類濃度範囲および幾何平 均は4.5 7, 500 ng-TEQ/g（平均310ng-TEQ/g）であっ た。PCP製剤中のダイオキシン類は, PCDDs, PCDFs と もに塩素数の多い異性体ほど濃度が高い傾向にあるのに
対し， $\mathrm{Co}-\mathrm{PCBs}$ は 1 検体を除き検査基準值未満であっ た。

PCPの製造方法は，ヘキサクロロベンゼン（HCB）を 水酸化する $\mathrm{HCB}$ 法とフェノールを塩素化するフェノー ル法がある。両製造方法毎にダイオキシン類濃度範囲お よび幾何平均を算出すると, HCB 法では4.5〜630ng$\mathrm{TEQ} / \mathrm{g}$ (平均38ng-TEQ/g)，フェノール法では320 7,500ng-TEQ/g（平均 $1,300 \mathrm{ng}-\mathrm{TEQ} / \mathrm{g}$ ) であり，フェ ノール法の場合にダイオキシン類濃度が高くなる傾向が 認められた。また，2，3，7，8位塩素置換 PCDD/Fsによる TEQへの寄与率を両製造方法別で比較すると（Fig. 2)， いずれの場合も $1,2,3,4,6,7,8-\mathrm{HpCDD}$ の寄与率が最も 高かった。しかし, 1,2,3,4,6,7,8-HpCDD 以外で寄与率 が高い異性体は，HCB 法では OCDD >1, 2,3,4, 7, 8$\mathrm{HxCDD} \geqq 1,2,3,7,8-\mathrm{PeCDD}>1,2,3,4,6,7,8-\mathrm{HpCDF}$ の順であるのに対し，フェノール法では1,2,3,6, 7, 8$\mathrm{HxCDD} \geqq 1,2,3,4,6,7,8-\mathrm{HpCDF}>\mathrm{OCDD}>1,2,3,4,7$, 8-HxCDF の順であった。これらのことから，製造方法 により PCP 製剤中 PCDD/Fs の濃度及び組成が異なるこ とが考えられた。

\section{1 . 2 CNP 製剤中ダイオキシン類濃度と組成}

$\mathrm{CNP}$ 製剤中のダイオキシン類濃度範囲および幾何平 均 (Table 4) は, 検査基準未満（<0.1ng-TEQ/g） 13,000ng-TEQ/g（平均33ng-TEQ/g）であった。なお検 査基準未満が 3 検体あったが，幾何平均値の算出にあ たっては検査基準值（0.1ng-TEQ/g）を用いた。CNP 製 剤の場合, PCP 製剂と比較してダイオキシン類濃度範 囲が大きいが，推定製造年別に見ると，1982年を境にそ の前後で明瞭な差が認められた。そこで, 推定製造年 
Table 3 Inspection standard ${ }^{19)}$ for dioxins analysis in pesticides

\begin{tabular}{|c|c|c|c|}
\hline Congeners & $\begin{array}{l}\text { Inspection } \\
\text { standard } \\
\text { (ng/g) } \\
\end{array}$ & Congeners & $\begin{array}{l}\text { Inspection } \\
\text { standard } \\
\text { (ng/g) } \\
\end{array}$ \\
\hline PCDDs & & Co-PCBs & \\
\hline 2,3,7,8-TCDD & 0.1 & $3,3^{\prime}, 4,4^{\prime}-\mathrm{TeCB}(\# 77)$ & 1000 \\
\hline 1,2,3,7,8-PeCDD & 0.1 & 3,4,4',5-ТeCB(\#81) & 1000 \\
\hline $1,2,3,4,7,8-\mathrm{HxCDD}$ & 1 & $3,3^{\prime}, 4,4,5-\mathrm{PeCB}(\# 126)$ & 1 \\
\hline $1,2,3,6,7,8-\mathrm{HxCDD}$ & 1 & $3,3^{\prime}, 4,4^{\prime}, 5,5^{\prime}-\mathrm{HxCB}(\# 169)$ & 10 \\
\hline $1,2,3,7,8,9-\mathrm{HxCDD}$ & 1 & $2,3,3^{\prime}, 4,4^{\prime}-\mathrm{PeCB}(\# 105)$ & 1000 \\
\hline $1,2,3,4,6,7,8-\mathrm{HpCDD}$ & 10 & $2,3,4,4,5-\mathrm{PeCB}(\# 114)$ & 200 \\
\hline \multirow[t]{2}{*}{ OctaCDD } & 1000 & 2,3',4,4',5-PeCB(\#118) & 1000 \\
\hline & & 2',3,4,4',5-PeCB(\#123) & 1000 \\
\hline PCDFs & & $2,3,3^{\prime} 4,4^{\prime}, 5-\mathrm{HxCB}(\# 156)$ & 200 \\
\hline 2,3,7,8-TCDF & 1 & $2,3,3^{\prime}, 4,4^{\prime}, 5^{\prime}-\mathrm{HxCB}(\# 157)$ & 200 \\
\hline $1,2,3,7,8-\mathrm{PeCDF}$ & 2 & $2,3^{\prime}, 4,4^{\prime}, 5,5^{\prime}-\mathrm{HxCB}(\# 167)$ & 10000 \\
\hline 2,3,4,7,8-PeCDF & 0.2 & $2,3,3^{\prime}, 4,4^{\prime}, 5,5^{\prime}-\mathrm{HpCB}(\# 189)$ & 1000 \\
\hline $1,2,3,4,7,8-\mathrm{HxCDF}$ & 1 & & \\
\hline $1,2,3,6,7,8-\mathrm{HxCDF}$ & 1 & & \\
\hline $1,2,3,7,8,9-\mathrm{HxCDF}$ & 1 & & \\
\hline $2,3,4,6,7,8-\mathrm{HxCDF}$ & 1 & & \\
\hline $1,2,3,4,6,7,8-\mathrm{HpCDF}$ & 10 & & \\
\hline $1,2,3,4,7,8,9-\mathrm{HpCDF}$ & 10 & & \\
\hline OctaCDF & 1000 & & \\
\hline
\end{tabular}
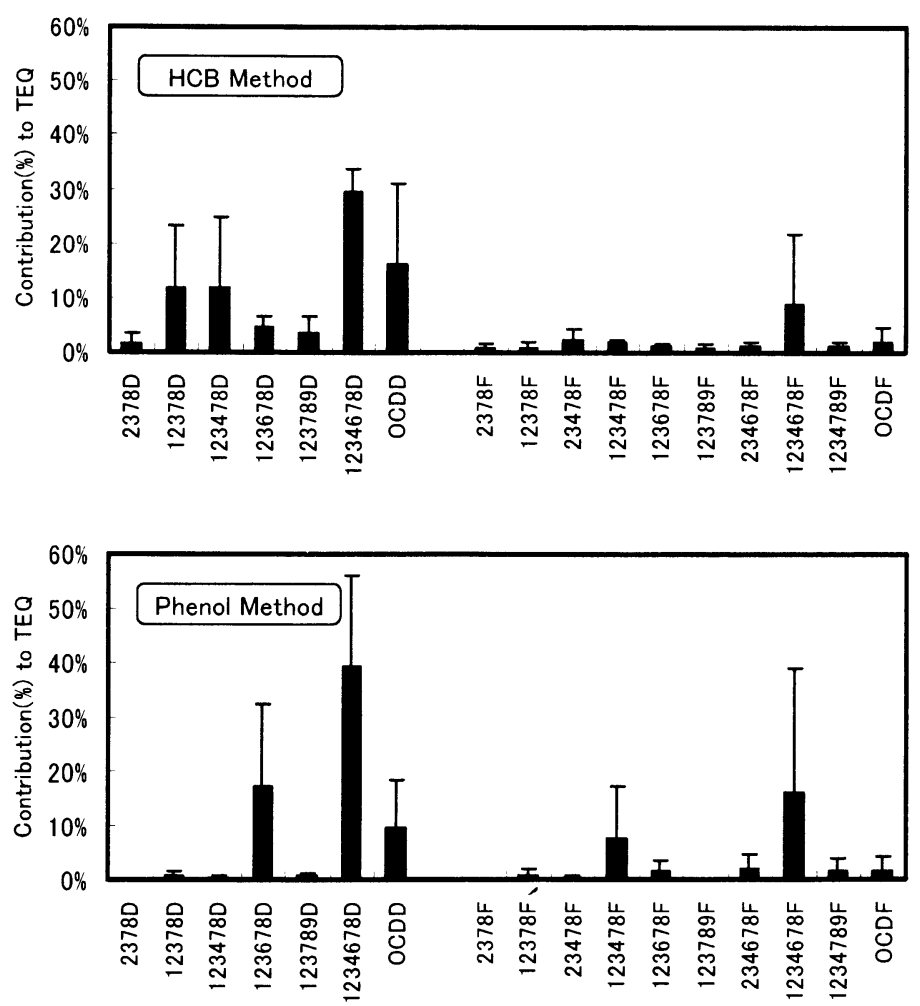

Fig. 2 Contribution (\%) to TEQ by 2,3,7,8-substituted congeners in PCP. Bars denote standard deviation of means 
Table 4 Concentrations (ng/g) of PCDD/Fs and Co-PCBs in PCP and CNP

\begin{tabular}{|c|c|c|c|c|c|c|c|c|c|c|}
\hline Chemical & PCP & PCP & PCP & $\mathrm{PCP}$ & PCP & PCP & PCP & PCP & PCP & PCP \\
\hline Estimated production date & 1966 & 1967 & 1969 & 1970 & 1972 & 1975 & 1977 & 1979 & 1982 & 1985 \\
\hline Expiry date & 1969 & 1970 & 1972 & 1973 & 1975 & 1978 & 1980 & 1982 & 1985 & 1988 \\
\hline Formulation* & G & G & G & G & W & w & W & w & G & w \\
\hline Manufacture method ${ }^{* *}$ & $\mathbf{P}$ & $\mathbf{P}$ & $\mathrm{H}$ & $\mathbf{P}$ & $\mathrm{H}$ & $\mathrm{P}$ & $\mathbf{P}$ & $\mathrm{P}$ & $\mathrm{H}$ & $\mathrm{H}$ \\
\hline Content of active ingredient & 25 & 25 & 25 & 25 & 86 & 25 & 86 & 86 & 25 & 25 \\
\hline $1,3,6,8-\mathrm{TeCDD}$ & 28 & 22 & 6.0 & 380 & 0.12 & 7.3 & 1.3 & 5.1 & 2.7 & 7.0 \\
\hline 1,3,7,9-TeCDD & 13 & 10 & 1.4 & 320 & $<0.1$ & 2.9 & $<0.1$ & 2.2 & 1.5 & 2.9 \\
\hline $2,3,7,8-\mathrm{TCDD}$ & 0.29 & $<0.1$ & 0.36 & 2.0 & 0.20 & $<0.1$ & $<0.1$ & $<0.1$ & $<0.1$ & 0.21 \\
\hline 1,2,3,7,8-PeCDD & 5.6 & 0.48 & 6.4 & 68 & 1.1 & 2.60 & 0.20 & 55 & 0.76 & 1.3 \\
\hline $1,2,3,4,7,8-\mathrm{HxCDD}$ & 44 & 5.6 & 110 & 190 & 24 & 34 & $<1$ & 340 & 5.6 & 3.2 \\
\hline 1,2,3,6,7,8-HxCDD & 640 & 240 & 16 & 8,400 & 4.0 & 2,200 & 160 & 14,000 & 400 & 3.1 \\
\hline $1,2,3,7,8,9-\mathrm{HxCDD}$ & 35 & 12 & 17 & 520 & 2.8 & 110 & 4.8 & 260 & 17 & 3.7 \\
\hline $1,2,3,4,6,7,8-\mathrm{HpCDD}$ & 19,000 & 6,800 & 1,100 & 480,000 & 690 & 41,000 & 31,000 & 120,000 & 18,000 & 130 \\
\hline OCDD & 76,000 & 720,000 & $<1,000$ & $14,000,000$ & 62,000 & 590,000 & 980,000 & 670,000 & $1,600,000$ & 3,300 \\
\hline $2,3,7,8-\mathrm{TCDF}$ & $<0.1$ & $<0.1$ & 2.0 & $<0.1$ & $<0.1$ & $<0.1$ & $<0.1$ & 2.0 & $<0.1$ & $<0.1$ \\
\hline $1,2,3,7,8-\mathrm{PeCDF}$ & 12 & 220 & 9.2 & 24 & $<2$ & 12 & $<2$ & 49 & $<2$ & $<2$ \\
\hline 2,3,4,7,8-PeCDF & 5.2 & $<0.2$ & 2.9 & 3.4 & 1.3 & 3.4 & 0.6 & 85 & $<0.2$ & 0.28 \\
\hline $1,2,3,4,7,8-\mathrm{HxCDF}$ & 680 & 760 & 9.2 & 840 & 2.9 & 240 & 160 & 770 & 120 & 1.1 \\
\hline $1,2,3,6,7,8-\mathrm{HxCDF}$ & 220 & 39 & 3.7 & 72 & 1.5 & 130 & 40 & 400 & 28 & $<1$ \\
\hline $1,2,3,7,8,9-\mathrm{HxCDF}$ & 10 & $<1$ & $<1$ & $<1$ & $<1$ & 6.7 & $<1$ & 50 & $<1$ & $<1$ \\
\hline $2,3,4,6,7,8-\mathrm{HxCDF}$ & 120 & 44 & 5.6 & 140 & 2.3 & 58 & 19 & 2,200 & 44 & $<1$ \\
\hline $1,2,3,4,6,7,8-\mathrm{HpCDF}$ & 4,800 & 3,700 & 88 & 18,000 & 36 & 4,900 & 90,000 & 15,000 & 18,000 & 13 \\
\hline $1,2,3,4,7,8,9-\mathrm{HpCDF}$ & 800 & 2,000 & $<10$ & 2,500 & $<10$ & 950 & 830 & 920 & 1,100 & $<10$ \\
\hline OCDF & 25,000 & 60,000 & $<1,000$ & 260,000 & $<1000$ & 28,000 & 970,000 & 11,000 & 380,000 & 280 \\
\hline TeCDDs & 60 & 48 & 960 & 1,600 & 85 & 26 & 2.3 & 13 & 13 & 21 \\
\hline PeCDDs & 92 & 26 & 560 & 2,100 & 34 & 34 & 1.9 & 90 & 38 & 13 \\
\hline HxCDDs & 3,000 & 480 & 240 & 20,000 & 58 & 5,500 & 220 & 23,000 & 680 & 43 \\
\hline HpCDDs & 26,000 & 8,400 & 1,200 & 720,000 & 1,400 & 63,000 & 36,000 & 170,000 & 24,000 & 200 \\
\hline OCDD & 76,000 & 720,000 & $<1000$ & $14,000,000$ & 62,000 & 590,000 & 980,000 & 670,000 & $1,600,000$ & 3,300 \\
\hline Total PCDDs & 110,000 & 730,000 & 3,000 & $15,000,000$ & 64,000 & 660,000 & $1,000,000$ & 860,000 & $1,600.000$ & 3,600 \\
\hline TeCDFs & 48 & 44 & 27 & 76 & 8.0 & 28 & 3.5 & 24 & 13 & 2.3 \\
\hline PeCDFs & 68 & 920 & 34 & 220 & 10 & 330 & 33 & 1,200 & 52 & 3.6 \\
\hline HxCDFs & 3,400 & 3,880 & 80 & 13,000 & 23 & 5,300 & 27,000 & 22,000 & 6,800 & 7.9 \\
\hline HpCDFs & 33,000 & 30,800 & 190 & 130,000 & 57 & 23,000 & 360,000 & 43,000 & 100,000 & 57 \\
\hline OCDF & 25,000 & 60,000 & $<1000$ & 260,000 & 220 & 28,000 & 970,000 & 11,000 & 380,000 & $<1,000$ \\
\hline Total PCDFs & 62,000 & 96,000 & 330 & 400,000 & 320 & 57,000 & $1,400,000$ & 77,000 & 490,000 & 71 \\
\hline Total PCDD/Fs & 170,000 & 800,000 & 3,800 & $15,000,000$ & 64,000 & 720,000 & $2,400,000$ & 940,000 & $2,100.000$ & 3,700 \\
\hline $3,3^{\prime}, 4,4^{\prime}-\mathrm{TeCB}(\# 77)$ & $<1,000$ & $<1,000$ & $<1,000$ & $<1,000$ & $<1,000$ & $<1,000$ & $<1,000$ & $<1,000$ & $<1,000$ & $<1,000$ \\
\hline $3,4,4 ', 5-\mathrm{TeCB}(\# 81)$ & $<1,000$ & $<1,000$ & $<1,000$ & $<1,000$ & $<1,000$ & $<1,000$ & $<1,000$ & $<1,000$ & $<1,000$ & $<1,000$ \\
\hline $3,3,4,4^{\prime}, 5-\mathrm{PeCB}(\# 126)$ & $<1$ & $<1$ & 1.9 & $<1$ & $<1$ & $<1$ & $<1$ & $<1$ & $<1$ & $<1$ \\
\hline $3,3 ' 4,4 ', 5,5^{\prime}-\mathrm{HxCB}(\# 169)$ & $<10$ & $<10$ & $<10$ & $<10$ & $<10$ & $<10$ & $<10$ & $<10$ & $<10$ & $<10$ \\
\hline $2,3,3^{\prime}, 4,4^{\prime}-\mathrm{PeCB}(\# 105)$ & $<1,000$ & $<1,000$ & $<1,000$ & $<1,000$ & $<1,000$ & $<1,000$ & $<1,000$ & $<1,000$ & $<1,000$ & $<1,000$ \\
\hline $2,3,4,4^{\prime}, 5-\mathrm{PeCB}(\# 114)$ & $<200$ & $<200$ & $<200$ & $<200$ & $<200$ & $<200$ & $<200$ & $<200$ & $<200$ & $<200$ \\
\hline $2,3,4,4,5-\mathrm{PeCB}(\# 118)$ & $<1,000$ & $<1,000$ & $<1,000$ & $<1,000$ & $<1,000$ & $<1,000$ & $<1,000$ & $<1,000$ & $<1,000$ & $<1,000$ \\
\hline $2 ', 3,4,4 ', 5-\mathrm{PeCB}(\# 123)$ & $<1,000$ & $<1,000$ & $<1,000$ & $<1,000$ & $<1,000$ & $<1,000$ & $<1,000$ & $<1,000$ & $<1,000$ & $<1,000$ \\
\hline $2,3,34,4^{\prime}, 5-\mathrm{HxCB}(\# 156)$ & $<200$ & $<200$ & $<200$ & $<200$ & $<200$ & $<200$ & $<200$ & $<200$ & $<200$ & $<200$ \\
\hline $2,3,3^{\prime}, 4,4^{\prime}, 5^{\prime}-\mathrm{HxCB}(\# 157)$ & $<200$ & $<200$ & $<200$ & $<200$ & $<200$ & $<200$ & $<200$ & $<200$ & $<200$ & $<200$ \\
\hline $2,3 ', 4,4 ', 5,5^{\prime}-\mathrm{HxCB}(\# 167)$ & $<10,000$ & $<10,000$ & $<10,000$ & $<10,000$ & $<10,000$ & $<10,000$ & $<10,000$ & $<10,000$ & $<10,000$ & $<10,000$ \\
\hline $2,3,3 ', 4,4^{\prime}, 5,5^{\prime}-\mathrm{HpCB}(\# 189)$ & $<1,000$ & $<1,000$ & $<1,000$ & $<1,000$ & $<1,000$ & $<1,000$ & $<1,000$ & $<1,000$ & $<1,000$ & $<1,000$ \\
\hline WHO-TEQ & 440 & 320 & 37 & 7,500 & 19 & 810 & 1,500 & 3,300 & 630 & 4.5 \\
\hline
\end{tabular}


Table 4 Continued

\begin{tabular}{|c|c|c|c|c|c|c|c|c|c|c|}
\hline Chemical & CNP & CNP & CNP & CNP & CNP & CNP & CNP & CNP & CNP & CNP \\
\hline Estimated production date & 1972 & 1973 & 1974 & 1975 & 1976 & 1977 & 1978 & 1979 & 1980 & 1981 \\
\hline Expiry date & 1975 & 1976 & 1977 & 1978 & 1979 & 1980 & 1981 & 1982 & 1983 & 1984 \\
\hline Formulation* & G & G & $\mathrm{E}$ & G & G & G & G & G & $\mathrm{E}$ & $\mathrm{E}$ \\
\hline Manufacture method ${ }^{* *}$ & - & - & - & - & - & - & - & - & - & - \\
\hline Content of active ingredient (\%) & 9 & 9 & 20 & 6 & 6 & 9 & 9 & 9 & 20 & 20 \\
\hline 1,3,6,8-TeCDD & $5,000,000$ & $3,900,000$ & $6,500,000$ & $5,800,000$ & $5,500,000$ & $4,100,000$ & $4,700,000$ & $4,800,000$ & $4,000,000$ & $3,600,000$ \\
\hline $1,3,7,9-\mathrm{TeCDD}$ & $1,700,000$ & $1,300,000$ & $2,400,000$ & $2,000,000$ & $1,800,000$ & $1,300,000$ & $1,700,000$ & $1,700,000$ & $1,500,000$ & $1,300,000$ \\
\hline $2,3,7,8-\mathrm{TCDD}$ & 170 & 110 & 230 & 220 & 130 & 52 & 89 & 120 & 35 & 45 \\
\hline $1,2,3,7,8-\mathrm{PeCDD}$ & 710 & 1,800 & 2,600 & 10,000 & 8,300 & 610 & 1,600 & 2,900 & 1,700 & 3,000 \\
\hline $1,2,3,4,7,8-\mathrm{HxCDD}$ & 11 & 66 & 80 & 420 & 430 & 21 & 79 & 140 & 70 & 140 \\
\hline $1,2,3,6,7,8-\mathrm{HxCDD}$ & 720 & 1,300 & 1,900 & 6,200 & 6,000 & 920 & 1,200 & 2,200 & 2,100 & 2,100 \\
\hline $1,2,3,7,8,9-\mathrm{HxCDD}$ & 280 & 500 & 750 & 2,200 & 2,200 & 320 & 470 & 820 & 700 & 750 \\
\hline $1,2,3,4,6,7,8-\mathrm{HpCDD}$ & 83 & 290 & 290 & 2,200 & 1,600 & 230 & 370 & 660 & 550 & 550 \\
\hline OCDD & $<1,000$ & $<1,000$ & $<1,000$ & $<1,000$ & $<1,000$ & $<1,000$ & $<1,000$ & $<1,000$ & $<1,000$ & $<1,000$ \\
\hline $2,3,7,8-\mathrm{TCDF}$ & 160 & 86 & 200 & 220 & 120 & 39 & 51 & 62 & 24 & 21 \\
\hline $1,2,3,7,8-\mathrm{PeCDF}$ & 77 & 120 & 200 & 520 & 300 & 41 & 100 & 170 & 85 & 125 \\
\hline 2,3,4.7,8-PeCDF & 87 & 160 & 250 & 900 & 550 & 41 & 110 & 210 & 120 & 160 \\
\hline $1,2,3,4,7,8-\mathrm{HxCDF}$ & 7.9 & 12 & 16 & 50 & 30 & 4.1 & 11 & 16 & 6.5 & 8.0 \\
\hline $1,2,3,6,7,8-\mathrm{HxCDF}$ & 41 & 67 & 110 & 250 & 220 & 22 & 53 & 87 & 60 & 85 \\
\hline $1,2,3,7,8,9-\mathrm{HxCDF}$ & 1.0 & $<1$ & $<1$ & $<1$ & $<1$ & $<1$ & $<1$ & $<1$ & $<1$ & $<1$ \\
\hline $2,3,4,6,7,8-H x C D F$ & 540 & 1,300 & 2,300 & 13,000 & 9,800 & 440 & 1,100 & 2,900 & 1,400 & 2,000 \\
\hline $1,2,3,4,6,7,8-\mathrm{HpCDF}$ & 27 & $<10$ & 95 & 430 & 280 & 32 & $<10$ & 120 & 70 & 95 \\
\hline $1,2,3,4,7,8,9-\mathrm{HpCDF}$ & $<10$ & $<10$ & $<10$ & $<10$ & $<10$ & $<10$ & $<10$ & $<10$ & $<10$ & $<10$ \\
\hline OCDF & $<1,000$ & $<1,000$ & $<1,000$ & $<1,000$ & $<1,000$ & $<1,000$ & $<1,000$ & $<1,000$ & $<1,000$ & $<1,000$ \\
\hline TeCDDs & $6,800,000$ & $5,400,000$ & $9,500,000$ & $8,000,000$ & $7,700,000$ & $5,600,000$ & $6,300,000$ & 650,000 & $5,500,000$ & $5,000,000$ \\
\hline PeCDDs & 320,000 & 510,000 & $1,000,000$ & $2,500,000$ & $1,800,000$ & 270,000 & 410,000 & 730,000 & 550,000 & 550,000 \\
\hline HxCDDs & 9,200 & 14,000 & 23,000 & 110,000 & 87,000 & 14,000 & 19,000 & 39,000 & 33,000 & 30,000 \\
\hline HpCDDs & 100 & 340 & 360 & 2,700 & 2,000 & 280 & 440 & 820 & 650 & 700 \\
\hline OCDD & $<1,000$ & $<1,000$ & $<1,000$ & 1,000 & $<1,000$ & $<1,000$ & $<1,000$ & $<1,000$ & $<1,000$ & $<1,000$ \\
\hline Total PCDDs & $7,100,000$ & $5,900,000$ & $11,000,000$ & $11,000,000$ & $9,600,000$ & $5,900,000$ & $6,700,000$ & $1,500,000$ & $6,100,000$ & $5,600,000$ \\
\hline TeCDFs & 160,000 & 190,000 & 340,000 & 270,000 & 270,000 & 80,000 & 140,000 & 160,000 & 160,000 & 220,000 \\
\hline PeCDFs & 19,000 & 36,000 & 55,000 & 120,000 & 95,000 & 11,000 & 29,000 & 49,000 & 32,000 & 47,000 \\
\hline HxCDFs & 2,100 & 3,700 & 6,000 & 27,000 & 18,000 & 2,200 & 3,300 & 7,200 & 4,400 & 5,000 \\
\hline HpCDFs & 34 & 97 & 110 & 530 & 330 & 42 & 77 & 140 & 80 & 110 \\
\hline OCDF & $<1,000$ & $<1,000$ & $<1,000$ & $<1,000$ & $<1,000$ & $<1,000$ & $<1,000$ & $<1,000$ & $<1,000$ & $<1,000$ \\
\hline Total PCDFs & 180,000 & 230,000 & 400,000 & 420,000 & 380,000 & 93,000 & 170,000 & 220,000 & 200,000 & 270,000 \\
\hline Total PCDD/Fs & $7,300,000$ & $6,200,000$ & $11,000,000$ & $11,000,000$ & $10,000,000$ & $6,000,000$ & $7,000,000$ & $1,700,000$ & $6,300,000$ & $5,900,000$ \\
\hline $3,3 ', 4,4^{\prime}-\mathrm{TCB}(\# 77)$ & $<1,000$ & $<1,000$ & $<1,000$ & $<1,000$ & $<1,000$ & $<1,000$ & $<1,000$ & $<1,000$ & $<1,000$ & $<1,000$ \\
\hline $3,4,4^{\prime}, 5-\mathrm{TCB}(\# 81)$ & $<1,000$ & $<1,000$ & $<1,000$ & $<1,000$ & $<1,000$ & $<1,000$ & $<1,000$ & $<1,000$ & $<1,000$ & $<1,000$ \\
\hline $3,3 ' 4,4 ', 5-\mathrm{PeCB}(\# 126)$ & $<1$ & $<1$ & $<1$ & $<1$ & $<1$ & $<1$ & $<1$ & $<1$ & $<1$ & $<1$ \\
\hline $3,3^{\prime}, 4,4^{\prime}, 5,5^{\prime}-\mathrm{HxCB}(\# 169)$ & $<10$ & $<10$ & $<10$ & $<10$ & $<10$ & $<10$ & $<10$ & $<10$ & $<10$ & $<10$ \\
\hline 2,3,3',4,4'-PeCB(\#105) & $<1,000$ & $<1,000$ & $<1,000$ & $<1,000$ & $<1,000$ & $<1,000$ & $<1,000$ & $<1,000$ & $<1,000$ & $<1,000$ \\
\hline $2,3,4,4^{\prime}, 5-\mathrm{PeCB}(\# 114)$ & $<200$ & $<200$ & $<200$ & $<200$ & $<200$ & $<200$ & $<200$ & $<200$ & $<200$ & $<200$ \\
\hline 2,$3 ;, 4,4,5-\mathrm{PeCB}(\# 118)$ & $<1,000$ & $<1,000$ & $<1,000$ & $<1,000$ & $<1,000$ & $<1,000$ & $<1,000$ & $<1,000$ & $<1,000$ & $<1,000$ \\
\hline 2',3,4,4',5-PeCB(\#123) & $<1,000$ & $<1,000$ & $<1,000$ & $<1,000$ & $<1,000$ & $<1,000$ & $<1,000$ & $<1,000$ & $<1,000$ & $<1,000$ \\
\hline $2,3,3^{\prime} 4,4^{\prime}, 5-\mathrm{HxCB}(\# 156)$ & $<200$ & $<200$ & $<200$ & $<200$ & $<200$ & $<200$ & $<200$ & $<200$ & $<200$ & $<200$ \\
\hline $2,3,3 ', 4,4^{\prime}, 5^{\prime}-\mathrm{HxCB}(\# 157)$ & $<200$ & $<200$ & $<200$ & $<200$ & $<200$ & $<200$ & $<200$ & $<200$ & $<200$ & $<200$ \\
\hline $2,3^{\prime}, 4,4^{\prime}, 5,5^{\prime}-\mathrm{HxCB}(\# 167)$ & $<10,000$ & $<10,000$ & $<10,000$ & $<10,000$ & $<10,000$ & $<10,000$ & $<10,000$ & $<10,000$ & $<10,000$ & $<10,000$ \\
\hline $2,3,3^{\prime}, 4,4^{\prime}, 5,5^{\prime}-\mathrm{HpCB}(\# 189)$ & $<1,000$ & $<1,000$ & $<1,000$ & $<1,000$ & $<1,000$ & $<1,000$ & $<1,000$ & $<1,000$ & $<1,000$ & $<1,000$ \\
\hline WHO-TEQ & 1,100 & 2,300 & 3,500 & 13,000 & 11,000 & 860 & 2,000 & 3,800 & 2,200 & 3,600 \\
\hline
\end{tabular}


Table 4 Continued

\begin{tabular}{|c|c|c|c|c|c|c|c|c|c|c|}
\hline Chemical & CNP & $\mathrm{CNP}$ & $\mathrm{CNP}$ & $\mathrm{CNP}$ & CNP & CNP & $\mathrm{CNP}$ & $\mathrm{CNP}$ & $\mathrm{CNP}$ & CNP \\
\hline Estimated production date & 1982 & 1983 & 1983 & 1985 & 1985 & 1988 & 1990 & 1991 & 1991 & 1991 \\
\hline Expiry date & 1985 & 1986 & 1986 & 1988 & 1988 & 1991 & 1993 & 1994 & 1994 & 1994 \\
\hline Formulation* & $\mathrm{E}$ & $\mathrm{T}$ & E & $\mathrm{E}$ & $\mathrm{E}$ & $\mathrm{E}$ & G & $\mathrm{E}$ & $\mathrm{E}$ & $\mathrm{E}$ \\
\hline Manufacture method ${ }^{* *}$ & - & - & - & - & - & - & - & - & - & - \\
\hline Content of active ingredient $(\%)$ & 20 & 96.3 & 20 & 20 & 20 & 20 & 9 & 20 & 20 & 20 \\
\hline $1,3,6,8-\mathrm{TeCDD}$ & $3,600,000$ & $2,000,000$ & 150,000 & 490.000 & 400,000 & 380,000 & 130,000 & 180,000 & 190,000 & 120,000 \\
\hline 1.3,7,9-TeCDD & $1,300,000$ & 630,000 & 50,000 & 110,000 & 150,000 & 110.000 & 60,000 & 85,000 & 75,000 & 50,000 \\
\hline 2,3,7,8-TCDD & 0.13 & $<0.1$ & 0.11 & $<0.1$ & $<0.1$ & $<0.1$ & $<0.1$ & $<0.1$ & 0.55 & $<0.1$ \\
\hline 1,2,3,7,8-PeCDD & 20 & 4.6 & 18 & 2.8 & 0.27 & 9.5 & $<0.1$ & 0.14 & 37 & $<0.1$ \\
\hline $1,2,3,4,7,8-\mathrm{HxCDD}$ & $<1$ & $<1$ & $<1$ & $<1$ & $<1$ & $<1$ & $<1$ & $<1$ & 1.1 & $<1$ \\
\hline $1,2,3,6,7,8-\mathrm{HxCDD}$ & 80 & 28 & 80 & 2.6 & $<1$ & 6.0 & $<1$ & $<1$ & 21 & $<1$ \\
\hline $1,2,3,7,8,9-\mathrm{HxCDD}$ & 31 & 10 & 29 & $<1$ & $<1$ & 2.4 & $<1$ & $<1$ & 12 & $<1$ \\
\hline $1,2,3,4,6,7,8-\mathrm{HpCDD}$ & 38 & $<10$ & 37 & $<10$ & $<10$ & $<10$ & $<10$ & $<10$ & $<10$ & $<10$ \\
\hline OCDD & $<1,000$ & $<1,000$ & $<1,000$ & $<1,000$ & $<1,000$ & $<1,000$ & $<1,000$ & $<1,000$ & $<1,000$ & $<1,000$ \\
\hline $2,3,7,8-\mathrm{TCDF}$ & $<0.1$ & $<0.1$ & $<0.1$ & $<0.1$ & $<0.1$ & $<0.1$ & $<0.1$ & $<0.1$ & $<0.1$ & $<0.1$ \\
\hline 1,2,3,7,8-PeCDF & 4.1 & $<2$ & 1.2 & $<2$ & $<2$ & $<2$ & $<2$ & $<2$ & $<2$ & $<2$ \\
\hline 2,3,4,7,8-PeCDF & 1.2 & 0.21 & 1.1 & $<0.2$ & $<0.2$ & 0.44 & $<0.2$ & $<0.2$ & 2.1 & $<0.2$ \\
\hline $1,2,3,4,7,8-\mathrm{HxCDF}$ & $<1$ & $<1$ & $<1$ & $<1$ & $<1$ & $<1$ & $<1$ & $<1$ & $<1$ & $<1$ \\
\hline $1,2,3,6,7,8-\mathrm{HxCDF}$ & $<1$ & $<1$ & $<1$ & $<1$ & $<1$ & $<1$ & $<1$ & $<1$ & 1.2 & $<1$ \\
\hline $1,2,3,7,8,9-\mathrm{HxCDF}$ & $<1$ & $<1$ & $<1$ & $<1$ & $<1$ & $<1$ & $<1$ & $<1$ & $<1$ & $<1$ \\
\hline $2,3,4,6,7,8-\mathrm{HxCDF}$ & 20 & 3.0 & 17 & 2.5 & $<1$ & 5.0 & $<1$ & $<1$ & 26 & $<1$ \\
\hline $1,2,3,4,6,7,8-\mathrm{HpCDF}$ & $<10$ & $<10$ & $<10$ & $<10$ & $<10$ & $<10$ & $<10$ & $<10$ & $<10$ & $<10$ \\
\hline $1,2,3,4,7,8,9-\mathrm{HpCDF}$ & $<10$ & $<10$ & $<10$ & $<10$ & $<10$ & $<10$ & $<10$ & $<10$ & $<10$ & $<10$ \\
\hline OCDF & $<1,000$ & $<1,000$ & $<1,000$ & $<1,000$ & $<1,000$ & $<1,000$ & $<1,000$ & $<1,000$ & $<1,000$ & $<1,000$ \\
\hline TeCDDs & $4,900,000$ & $2,600,000$ & 200,000 & 600,000 & 550,000 & 490,000 & 220,000 & 270,000 & 300.000 & 170,000 \\
\hline PeCDDs & 70,000 & 24,000 & 3,100 & 950 & 600 & 2,300 & 92 & 80 & 6,000 & 65 \\
\hline $\mathrm{HxCDDs}$ & 2,400 & 1,200 & 140 & 39 & 4.7 & 90 & $<1$ & 1.6 & 290 & $<1$ \\
\hline HpCDDs & 65 & 17 & 75 & $<10$ & $<10$ & $<10$ & $<10$ & $<10$ & $<10$ & $<10$ \\
\hline OCDD & $<1,000$ & $<1,000$ & $<1,000$ & $<1,000$ & $<1,000$ & $<1,000$ & $<1,000$ & $<1,000$ & $<1,000$ & $<1,000$ \\
\hline Total PCDDs & $5,000,000$ & $2,600,000$ & 200,000 & 600,000 & 550,000 & 490,000 & 220,000 & 270,000 & 310,000 & 170,000 \\
\hline TeCDFs & 2,300 & 1,800 & 180 & 490 & 85 & 550 & 530 & 1,600 & 3,300 & 1,100 \\
\hline PeCDFs & 390 & 59 & 24 & 55 & 10 & 120 & 3.7 & 7.0 & 380 & 1.7 \\
\hline HxCDFs & 75 & 12 & 55 & 7.0 & 1.4 & 16 & $<1$ & $<1$ & 47 & $<1$ \\
\hline HpCDFs & $<10$ & $<10$ & $<10$ & $<10$ & $<10$ & $<10$ & $<10$ & $<10$ & $<10$ & $<10$ \\
\hline OCDF & $<1,000$ & $<1,000$ & $<1,000$ & $<1,000$ & $<1,000$ & $<1,000$ & $<1,000$ & $<1,000$ & $<1,000$ & $<1,000$ \\
\hline Total PCDFs & 2,800 & 1,900 & 260 & 550 & 96 & 690 & 530 & 1,600 & 3,700 & 1,100 \\
\hline Total PCDD/Fs & $5,000,000$ & $2,600,000$ & 200,000 & 600,000 & 550,000 & 490,000 & 220,000 & 270,000 & 310,000 & 170,000 \\
\hline $3,3^{\prime}, 4,4^{\prime}-\mathrm{TCB}(\# 77)$ & $<1,000$ & $<1,000$ & $<1,000$ & $<1,000$ & $<1,000$ & $<1,000$ & $<1,000$ & $<1,000$ & $<1,000$ & $<1,000$ \\
\hline $3,4,4,5-\mathrm{TCB}(\# 81)$ & $<1,000$ & $<1,000$ & $<1,000$ & $<1,000$ & $<1,000$ & $<1,000$ & $<1,000$ & $<1,000$ & $<1,000$ & $<1,000$ \\
\hline $3,3,4,4^{\prime}, 5-\mathrm{PeCB}(\# 126)$ & $<1$ & $<1$ & $<1$ & $<1$ & $<1$ & $<1$ & $<1$ & $<1$ & $<1$ & $<1$ \\
\hline $3,3^{\prime}, 4,4^{\prime}, 5,5^{\prime}-\mathrm{HxCB}(\# 169)$ & $<10$ & $<10$ & $<10$ & $<10$ & $<10$ & $<10$ & $<10$ & $<10$ & $<10$ & $<10$ \\
\hline 2,3,3',4,4'-PeCB(\#105) & $<1,000$ & $<1,000$ & $<1,000$ & $<1,000$ & $<1,000$ & $<1,000$ & $<1,000$ & $<1,000$ & $<1,000$ & $<1.000$ \\
\hline $2,3,4,4,5-\mathrm{PeCB}(\# 114)$ & $<200$ & $<200$ & $<200$ & $<200$ & $<200$ & $<200$ & $<200$ & $<200$ & $<200$ & $<200$ \\
\hline $2,3 ', 4,4^{\prime}, 5-\mathrm{PeCB}(\# 118)$ & $<1,000$ & $<1,000$ & $<1,000$ & $<1,000$ & $<1,000$ & $<1,000$ & $<1,000$ & $<1,000$ & $<1,000$ & $<1,000$ \\
\hline 2',3,4,4',5-PeCB(\#123) & $<1,000$ & $<1.000$ & $<1,000$ & $<1,000$ & $<1,000$ & $<1,000$ & $<1,000$ & $<1,000$ & $<1,000$ & $<1,000$ \\
\hline $2.3,3^{\prime} 4,4^{\prime}, 5-\mathrm{HxCB}(\# 156)$ & $<200$ & $<200$ & $<200$ & $<200$ & $<200$ & $<200$ & $<200$ & $<200$ & $<200$ & $<200$ \\
\hline $2,3,3^{\prime}, 4,4^{\prime}, 5^{\prime}-\mathrm{HxCB}(\# 157)$ & $<200$ & $<200$ & $<200$ & $<200$ & $<200$ & $<200$ & $<200$ & $<200$ & $<200$ & $<200$ \\
\hline $2,3^{\prime}, 4,4^{\prime}, 5,5^{\prime}-\mathrm{HxCB}(\# 167)$ & $<10,000$ & $<10,000$ & $<10,000$ & $<10,000$ & $<10,000$ & $<10,000$ & $<10,000$ & $<10,000$ & $<10,000$ & $<10,000$ \\
\hline $2,3,3 ', 4,4^{\prime}, 5,5 '-\mathrm{HpCB}(\# 189)$ & $<1,000$ & $<1,000$ & $<1,000$ & $<1,000$ & $<1,000$ & $<1,000$ & $<1,000$ & $<1,000$ & $<1,000$ & $<1,000$ \\
\hline WHO-TEQ & 34 & 8.8 & 32 & 3.3 & 0.27 & 11 & $<0.1$ & 0.14 & 45 & $<0.1$ \\
\hline
\end{tabular}

${ }^{*} \mathrm{E}$;Emulsifinable concentrate, T; Technical product, G;Granule, 
Table 4 Continued

\begin{tabular}{|c|c|c|c|c|}
\hline Chemical & CNP & CNP & CNP & CNP \\
\hline Estimated production date & 1992 & 1992 & 1993 & 1994 \\
\hline Expiry date & 1995 & 1995 & 1996 & 1997 \\
\hline Formulation* & $\mathrm{G}$ & $\mathrm{G}$ & G & $\mathrm{E}$ \\
\hline Manufacture method ${ }^{* *}$ & - & - & - & - \\
\hline Content of active ingredient (\%) & 9 & 9 & 9 & 20 \\
\hline $1,3,6,8-\mathrm{TeCDD}$ & 100,000 & 140,000 & 140,000 & 260,000 \\
\hline $1,3,7,9-\mathrm{TeCDD}$ & 44,000 & 66.000 & 63,000 & 110,000 \\
\hline 2,3,7,8-TCDD & $<0.1$ & $<0.1$ & $<0.1$ & $<0.1$ \\
\hline $1,2,3,7,8-\mathrm{PeCDD}$ & 0.12 & $<0.1$ & $<0.1$ & 0.24 \\
\hline $1,2,3,4,7,8-\mathrm{HxCDD}$ & $<1$ & $<1$ & $<1$ & $<1$ \\
\hline $1,2,3,6,7,8-\mathrm{HxCDD}$ & $<1$ & 13 & $<1$ & $<1$ \\
\hline $1,2,3,7,8,9-\mathrm{HxCDD}$ & $<1$ & 5.0 & $<1$ & $<1$ \\
\hline $1,2,3,4,6,7,8-\mathrm{HpCDD}$ & $<10$ & $<10$ & $<10$ & $<10$ \\
\hline OCDD & $<1.000$ & $<1,000$ & $<1,000$ & $<1,000$ \\
\hline $2,3,7,8-\mathrm{TCDF}$ & $<0.1$ & $<0.1$ & $<0.1$ & $<0.1$ \\
\hline $1,2,3,7,8-\mathrm{PeCDF}$ & $<2$ & $<2$ & $<2$ & $<2$ \\
\hline 2,3,4,7,8-PeCDF & $<0.2$ & $<0.2$ & $<0.2$ & $<0.2$ \\
\hline $1,2,3,4,7,8-\mathrm{HxCDF}$ & $<1$ & $<1$ & $<1$ & $<1$ \\
\hline $1,2,3,6,7,8-\mathrm{HxCDF}$ & $<1$ & $<1$ & $<1$ & $<1$ \\
\hline $1,2,3,7,8,9-\mathrm{HxCDF}$ & $<1$ & $<1$ & $<1$ & $<1$ \\
\hline $2,3,4,6,7,8-\mathrm{HxCDF}$ & $<1$ & $<1$ & $<1$ & $<1$ \\
\hline $1,2,3,4,6,7,8-\mathrm{HpCDF}$ & $<10$ & $<10$ & $<10$ & $<10$ \\
\hline 1,2,3,4,7,8,9-HpCDF & $<10$ & $<10$ & $<10$ & $<10$ \\
\hline OCDF & $<1,000$ & $<1,000$ & $<1,000$ & $<1,000$ \\
\hline TeCDDs & 140,000 & 210,000 & 200,000 & 270,000 \\
\hline PeCDDs & 96 & 280 & 200 & 250 \\
\hline HxCDDs & 1.3 & 91 & $<1$ & 1.3 \\
\hline HpCDDs & $<10$ & $<10$ & $<10$ & $<10$ \\
\hline OCDD & $<1,000$ & $<1,000$ & $<1,000$ & $<1,000$ \\
\hline Total PCDDs & 140.000 & 210,000 & 200,000 & 270,000 \\
\hline TeCDFs & 1,400 & 2,000 & 1,600 & 1,500 \\
\hline PeCDFs & 5.1 & 8.3 & 12 & 20 \\
\hline HxCDFs & $<1$ & 1 & $<1$ & $<1$ \\
\hline HpCDFs & $<10$ & $<10$ & $<10$ & $<10$ \\
\hline OCDF & $<1,000$ & $<1,000$ & $<1,000$ & $<1,000$ \\
\hline Total PCDFs & 1,400 & 2,000 & 1.600 & 1.500 \\
\hline Total PCDD/Fs & 140,000 & 210,000 & 200,000 & 270,000 \\
\hline $3,3,4,4-\mathrm{TCB}(\# 77)$ & $<1,000$ & $<1,000$ & $<1,000$ & $<1,000$ \\
\hline $3,4,4,5-\mathrm{TCB}(\# 81)$ & $<1,000$ & $<1,000$ & $<1,000$ & $<1,000$ \\
\hline 3,3',4,4'5-PeCB(\#126) & $<1$ & $<1$ & $<1$ & $<1$ \\
\hline $3,3,4,4^{\prime}, 5,5 '-\mathrm{HxCB}(\# 169)$ & $<10$ & $<10$ & $<10$ & $<10$ \\
\hline $2,3,3 ', 4,4^{\prime} \cdot \mathrm{PeCB}(\# 105)$ & $<1,000$ & $<1,000$ & $<1,000$ & $<1,000$ \\
\hline $2,3,4,4,5-\mathrm{PeCB}(\# 114)$ & $<200$ & $<200$ & $<200$ & $<200$ \\
\hline $2,3,4,4: 5-\mathrm{PeCB}(\# 118)$ & $<1,000$ & $<1.000$ & $<1,000$ & $<1.000$ \\
\hline 2',3,4,4'5-PeCB(\#123) & $<1,000$ & $<1,000$ & $<1,000$ & $<1,000$ \\
\hline $2,3,34,4 ;, 5-\mathrm{HxCB}(\# 156)$ & $<200$ & $<200$ & $<200$ & $<200$ \\
\hline $2,3,3^{\prime}, 4,4^{\prime}, 5^{\prime} \cdot \mathrm{HxCB}(\# 157)$ & $<200$ & $<200$ & $<200$ & $<200$ \\
\hline 2,$3 ; 4,4,5,5^{\prime} \cdot \mathrm{HxCB}(\# 167)$ & $<10,000$ & $<10,000$ & $<10,000$ & $<10,000$ \\
\hline $2,3,3,4,4,5,5 '-\mathrm{HpCB}(\# 189)$ & $<1,000$ & $<1,000$ & $<1,000$ & $<1,000$ \\
\hline WHO-TEQ & 0.12 & 1.8 & $<0.1$ & 0.24 \\
\hline
\end{tabular}

1972～1981年と1982～1994年の 2 期間に分けてダイオキ シン類濃度範囲および幾何平均を算出した。その結果, 推定製造年1972～1981年では860～13, 000ng-TEQ/g（平 均3, 000ng-TEQ/g）であり，推定製造年1982～1994年で は検査基準未満（<0. 1ng-TEQ/g）～45ng-TEQ/g（平均 $1.3 \mathrm{ng}-\mathrm{TEQ} / \mathrm{g})$ となり，平均值では前者の230分の 1 に なっていた。一方, TEQへの寄与率を両期間で比較する と（Fig. 3)，両者ともに1,2,3, 7,8-PeCDD の寄与率が 最も高く，その他の異性体でも種類および寄与率に大き な違いは認められなかった。これらのことから，1982年
以降では精製といった何らかの製造方法の変化があった ものと推測される。

\section{1. 3 PCP と CNP 製㓮に由来するダイオキシン 類総量の推定}

1958年から1994年における PCP および CNP 製剤に由 来するダイオキシン類の総量を, 両製剤中のダイオキシ ン類濃度 (最小值, 最大值, 平均值) に各年度の国内出 荷量 ${ }^{13)}$ を乗じることにより推定した。PCP 製剤中のダイ オキシン類濃度は3，1１項で算出した最小値 (4.5ng-TEQ/g) と最大值 $(7,500 \mathrm{ng}-\mathrm{TEQ} / \mathrm{g})$, そして平 均値は製法毎の幾何平均值に出荷量による加重平均をし た值（740ng-TEQ/g）を用いた。CNP 製剤中のダイオキ シン類濃度は，3．1．２項で算出した推定製造年1972 〜 1981年，および1982〜1994年のダイオキシン類濃度の 最小値, 最大值, 平均值をそれぞれ用いた。その結果, 両製剂に由来するダイオキシン類の総量は, PCPでは $0.84 \sim 1,300 \mathrm{~kg}-\mathrm{TEQ}$ (平均 $120 \mathrm{~kg}-\mathrm{TEQ}$ ), CNP では50〜 $760 \mathrm{~kg}-\mathrm{TEQ}$ (平均 $180 \mathrm{~kg}-\mathrm{TEQ}$ ) と算出された。Masunaga $ら^{11)}$ も PCP 製剤からは440kg-TEQ, CNP 製剤からは220 ～270kg-TEQ と推定しており, 本研究の推定值とほほ 一致していた。Fig. 4 に両製剤に由来するダイオキシン 類総量の算出値 (平均値) の経時変化を示した。この算 出值から1960年代前半は PCP 製剂に由来するダイオキ シン類で占められ，1960年後半から CNP 製剤に由来す るダイオキシン類が増加し，1970年代以降は CNP 製剤 由来で占められていたと推察された。

両製剤に由来するダイオキシン類総量を基に, 現在の 水田土壤中ダイオキシン類濃度を試算した。なお, 両製 剂が全国で均一に使用され，PCP，CNP両製剤以外に は, ダイオキシン類の含有が指摘されている農薬の水田 への施用は無いと仮定し，また，土壤中ダイオキシン類

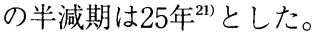

$$
\begin{aligned}
& \mathrm{Cp}=\sum_{\mathrm{n}=1965}^{1991}\left[\mathrm{Ep} / 2^{(2002-\mathrm{n}) / 25} / \mathrm{S} / \mathrm{H} / \mathrm{D}\right] \\
& \mathrm{Cc}=\sum_{\mathrm{n}=1958}^{1994}\left[\mathrm{Ec} / 2^{(2002-\mathrm{n}) / 25} / \mathrm{S} / \mathrm{H} / \mathrm{D}\right]
\end{aligned}
$$

まず，PCP， CNP 製剤に由来する水田土䁃中ダイオキ シン類濃度を次式により算出した。

$\mathrm{Cp}$ ：PCP 製剂に由来する水田土壤中ダイオキシン類 濃度 $(\mathrm{pg}-\mathrm{TEQ} / \mathrm{g})$

$\mathrm{Cc} ： \mathrm{CNP}$ 製剂に由来する水田土塞中ダイオキシン類 濃度 $(\mathrm{pg}-\mathrm{TEQ} / \mathrm{g})$

$\mathrm{Ep}: \mathrm{n}$ 年の $\mathrm{PCP}$ 製剤に由来するダイオキシン類総量 $(\mathrm{pg}-\mathrm{TEQ})$

$\mathrm{Ec} ＼textrm{n}$ 年の CNP 製剤に由来するダイオキシン類総量 (pg-TEQ)

$\mathrm{S}: \mathrm{n}$ 年の水稲作付面積 ${ }^{22}\left(\mathrm{~cm}^{2}\right)$ 
$\mathrm{H}$ : 深さ $(\mathrm{cm})$, ここでは $30 \mathrm{~cm}^{23)}$ とした

$\mathrm{D}$ : 土壌密度 $\left(\mathrm{g} / \mathrm{cm}^{3}\right)$, ここでは $1.2 \mathrm{~g} / \mathrm{cm}^{3}$ とした

その結果, PCP 製剤由来は0.026 43pg-TEQ/g（平均

$4.3 \mathrm{pg}-\mathrm{TEQ} / \mathrm{g}$ ), CNP 製剤由来は2.6 39pg-TEQ $/ \mathrm{g}$ (平
均 $9.2 \mathrm{pg}-\mathrm{TEQ} / \mathrm{g})$ と計算され，両製郕に由来する水田土 壤中ダイオキシン類濃度は2.6 82pg-TEQ/g（平均 $14 \mathrm{pg}-\mathrm{TEQ} / \mathrm{g}$ ) と推測された。環境省と農林水産省によ る平成 12 年度農用地土壤㧍よ゙゙農作物に係るダイオキシ
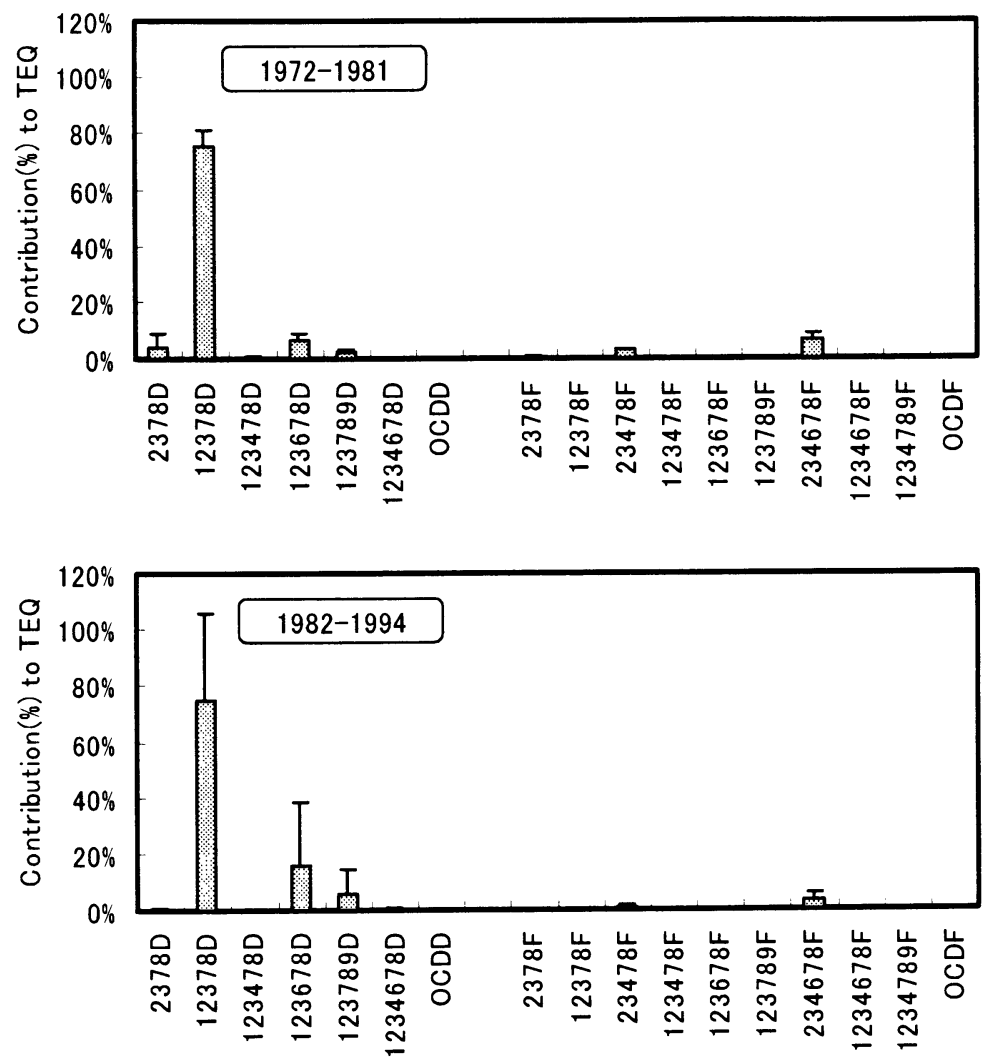

Fig. 3 Contribution (\%) to TEQ by 2,3,7,8-substituted congeners in CNP Bars denote standard deviation of means

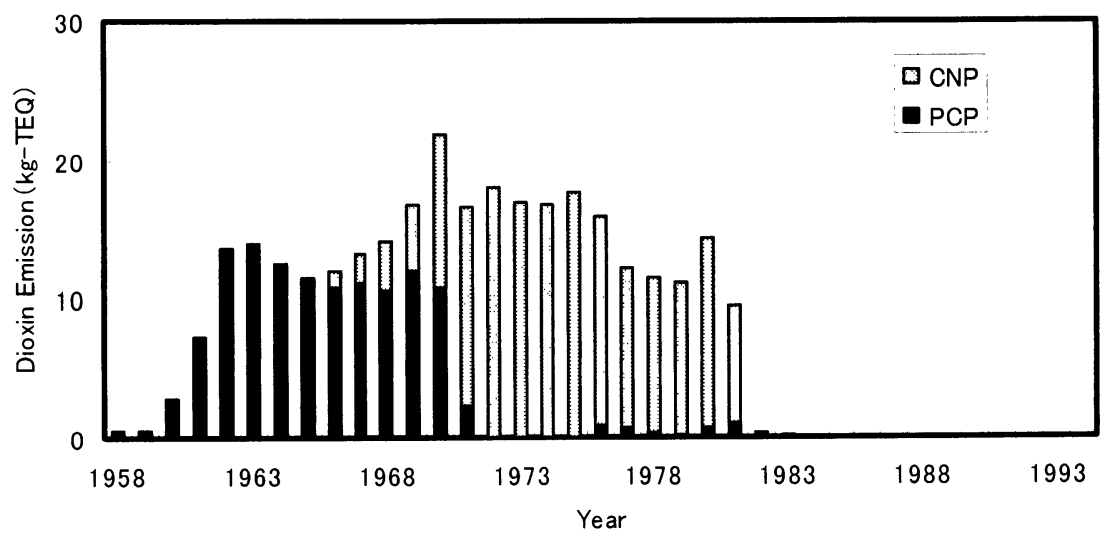

Fig. 4 Temporal change of estimated dioxin emissions from PCP and CNP from 1958 to 1994 
ン類実態調査結果 ${ }^{24)}$ では, 水田土壤中ダイオキシン類濃 度は5.3〜 180 (平均 $44 \mathrm{pg}-\mathrm{TEQ} / \mathrm{g}$ ) となっており, 今回の 試算值とよく一致する。

次に, PCP と CNP 製剤に由来する $2,3,7,8$ - 位塩素置 換 PCDD/Fs 異性体毎の総量を算出した結果 (Fig. 5 ), 塩素数が多い異性体ほど多い傾向にあり，99\%以上が PCP 製剤に由来していた。その内訳は，7,8塩素化物は $\mathrm{PCP}$ 製剤に，4,5塩素化物は CNP 製剤に由来していた。 6 塩素化物については異性体によって両製剤に由来する 割合が異なっていた。

$\mathrm{PCDD} / \mathrm{Fs}$ 異性体毎の総量を $\mathrm{TEQ}$ に換算すると, 約 $40 \%$ が PCP 製剤に由来し, 約 $60 \%$ が CNP 製剤に由来し ていた。また, 1,2,3,7,8-PeCDD >1,2,3,4,6, 7,8$\mathrm{HpCDD}>1,2,3,6,7,8-\mathrm{HxCDD}$ の順で TEQ への寄与率 が大きく (Fig. 6), これらの異性体により約70\%が占め られていた。1,2,3,7,8-PeCDD では99\%以上が CNP 製 剂に由来し, 1, 2,3,4,6,7,8-HpCDDはPCP 製剂に, 1,2,3,6,7,8-HxCDD は両者に由来していた。しかし, PCDFs 異性体による寄与は少なく, 総量の場合とは異 なる傾向を示した。

\section{2 水田土壤中ダイオキシン類の推移 \\ 3. 2.1 濃度の推移}

Fig. 7 に1960年から1999年における水田土壤中ダイオ キシン類濃度および TEQの推移を示す。ダイオキシン 類濃度およびTEQの範囲は, それぞれ2,700〜 130,000pg/g-dry と9.8～210pg-TEQ/g-dry であり，60年 代初期から上昇し，1970年代以降緩やかに減少している ことが分かった。1999年の分析值は48pg-TEQ/g-dry で あり, 環境省と農林水産省による調査結果 ${ }^{24)} の$ 平均值 (44pg-TEQ/g-dry) とほほ一致し, 代表的な水田土壤の サンプルであると考えられる。このような保存土壤中
$\mathrm{PCDD} / \mathrm{Fs}$ に関する報告例は数少なく ${ }^{25,26)}$, 非常に貴重で ある。

Fig. 8 にCDD, 1,3,6,8-TeCDDそし て1,3,7,9$\mathrm{TeCDD}$ 濃度の推移を示す。OCDD 濃度は1960年代前半 がピークで，その後減少傾向にある。また，1,3,6,8TeCDD と1,3, 7, 9-TeCDD 濃度は1960年代後半から 1970 年代前半がピークで, その後緩やかに減少しており,こ れらの異性体濃度のピーク時期に相違が見られる。 OCDD はPCP 製剤中に, 1,3,6,8-TeCDD と1,3, 7,9TeCDD は CNP 製剤中に主要な成分として含まれる異性 体であり (Table 4), これらの異性体濃度の推移は, Fig. 1に示したPCP と CNPの国内出荷量の推移 ${ }^{13)}$ と一致 している。これらのことから,この水田ではPCP と $\mathrm{CNP}$ 両製剤が使用され, 水田土塞中の PCDD/Fs, 特に OCDD と 1,3,6,8-TeCDD および1,3,7,9-TeCDD は, 両 製剂の寄与が大きいものと推察される。

\section{2.2 TEQ への寄与率の推移}

Fig. 9 に1, 2, 3, 7, 8-PeCDD, 1, 2, 3, 6, 7,8-HxCDD, 1,2, 3, 4, 6, 7,8-HpCDD, Other PCDDs, PCDFs おょび $\mathrm{Co}^{-}$ $\mathrm{PCBs}$ による TEQの寄与率の推移を示した。これらの中 で1, 2,3, 7,8-PeCDD, 1,2,3,6,7,8-HxCDD および1,2, 3, 4, 6, 7,8-HpCDD が TEQへの寄与率が高く, これらの 異性体により 60 ～80\%が占められていた。一方， $\mathrm{Co}^{-}$ PCBs による寄与はほとんど無かった。1960年代以降, 寄与率が減少傾向にあるのは1,2,3,4,6, 7, 8-HpCDD, 1,2,3,6,7,8-HxCDD および Other PCDDsであった。増 加傾向にあるのは $1,2,3,7,8-\mathrm{PeCDD}$ とCDFsであっ た。減少傾向にある $1,2,3,4,6,7,8-\mathrm{HpCDD}$ と 1,2 , $3,6,7,8-\mathrm{HxCDD}$ はPCP 製剤中でも寄与率が高く (Fig. 2)，その推移はPCP 製剤の影響が大きいと考えら れる。一方, 増加傾向にある1,2,3,7,8-PeCDD は CNP 製剂中で寄与率が高く (Fig. 3$)$ ，その推移は CNP 製剤

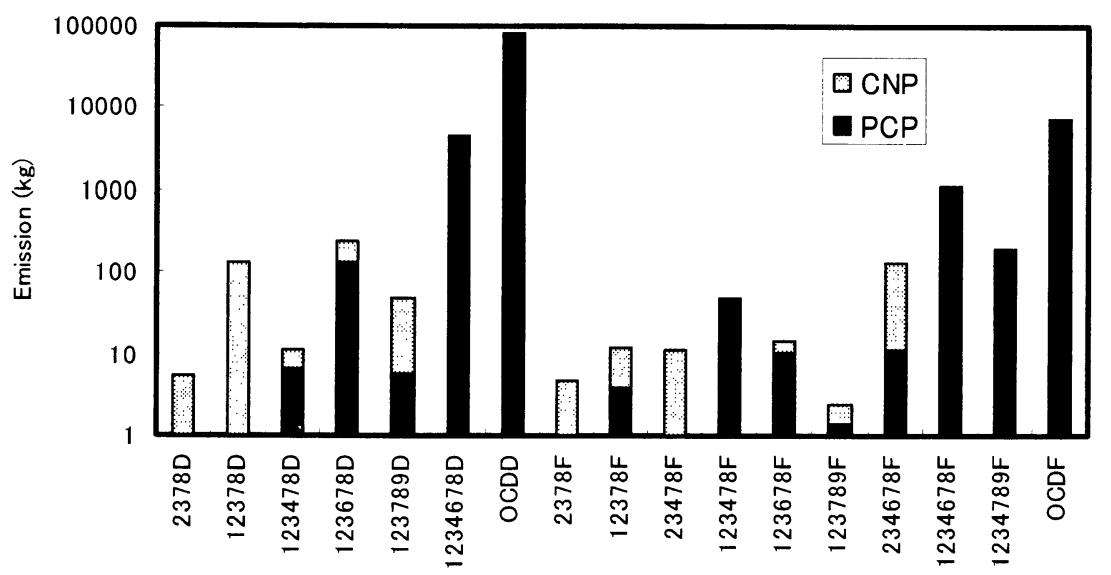

Fig. 5 Estimated emissions of 2,3,7,8-substituted congeners from PCP and CNP from 1958 to 1994 


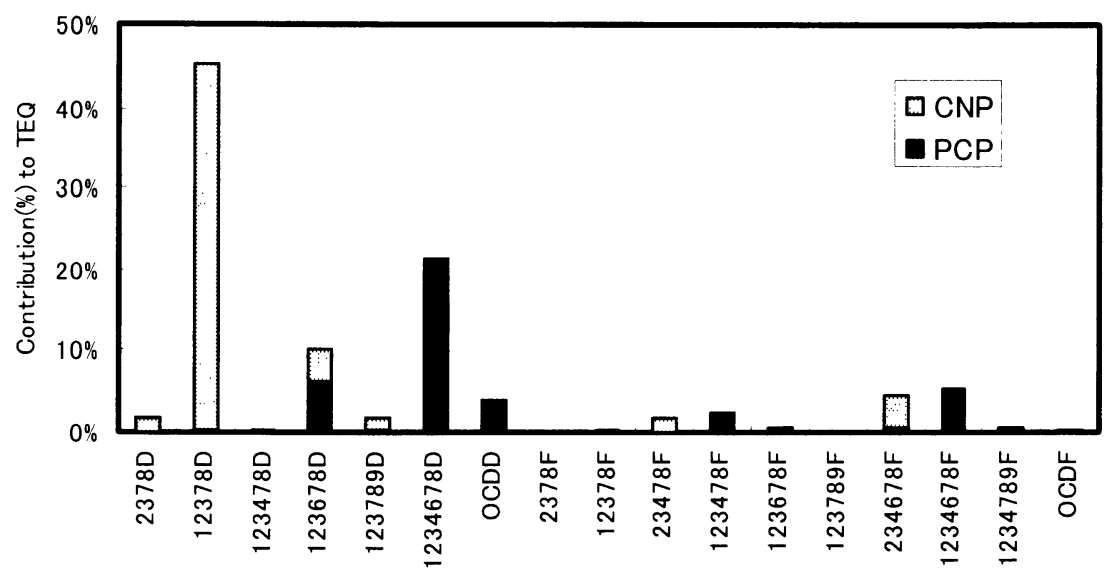

Fig. 6 Contributiom (\%) to TEQ by 2,3,7,8-substituted congeners in PCP and CNP

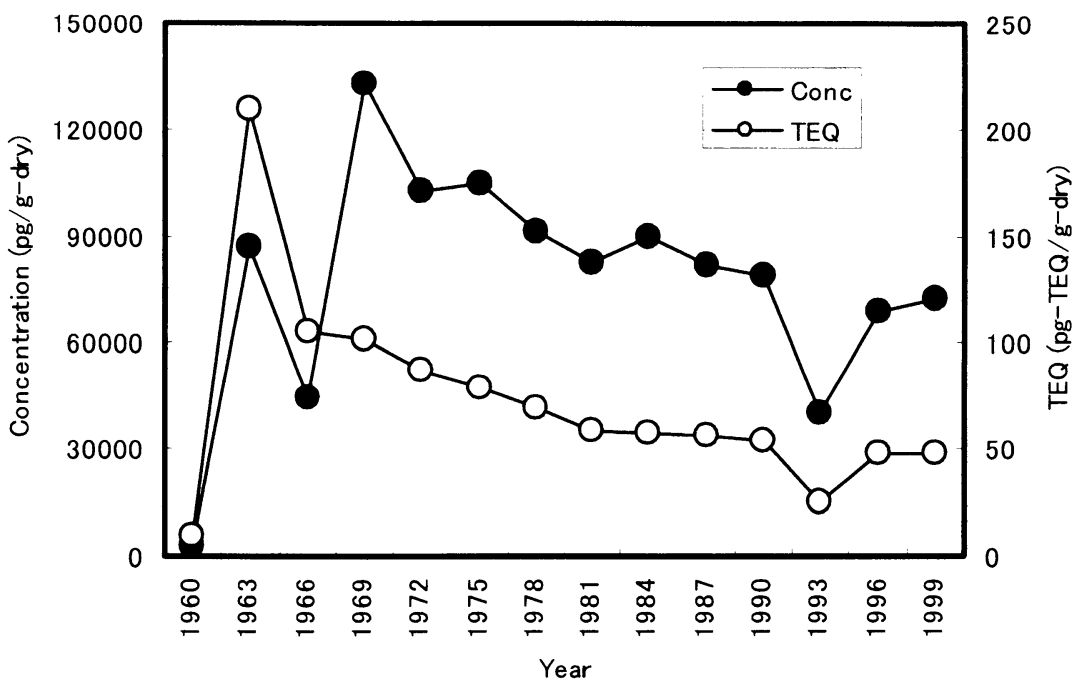

Fig. 7 Temporal change of PCDD/Fs and Co-PCBs concentrations and TEQ in paddy soils

の影響が大きいと考えられる。しかし，PCDFsについて は, CNP 製剤中の PCDFsによる寄与率は非常に低く， CNP 製剂からだけでは説明できない。

そこで，これらの推移を統計的に解析するために，主 成分分析を用いた（Fig.10）。解析に用いたデータは，水 田土壤（1960～1999年），Fig. 2 で示したPCP製剤（HCB 法とフェノール法)，Fig. 3 で示した CNP 製剤（1972〜 1981年および1982～1994年)，および非農耕地土壤中 ${ }^{27)}$ 2,3,7,8- 位塩素置換 PCDD/Fs の TEQへの寄与率であ る。なお, Co-PCBs については, 水田土壤において TEQ への寄与がほとんど無いこと, PCP, CNP 両製剤中では ほとんどが検査基準值以下であるため（Table 4）, 解析 から除外した。
第 1 主成分（寄与率 $84 \%$ ）の固有ベクトルは, 1,2, 3, 7, 8-PeCDD や2, 3, 4, 6, 7, 8-HxCDF といった CNP 製剂中で寄与率の高い異性体が正の值を取り, $1,2,3,4,6,7,8-\mathrm{HpCDD}$ といった PCP 製剤中で寄与率の 高い異性体が負の值を取っている。このことから, 第 1 主成分は PCP と CNP両製剤の寄与と解釈できる。一方, 第 2 主成分（寄与率7.1\%）の固有ベクトルは, PCDDs 異性体が正の值を取り，PCDFs 異性体が負の值を取っ ている。このことから, 第 2 主成分はPCDDsおよび PCDFsによる寄与と解釈できる。Fig.10における PCP, $\mathrm{CNP}$ 両製剤の主成分得点によるプロットは, これらの解 釈を支持する結果を示している。

水田土壤の主成分得点によるプロット（Fig.10）は, 


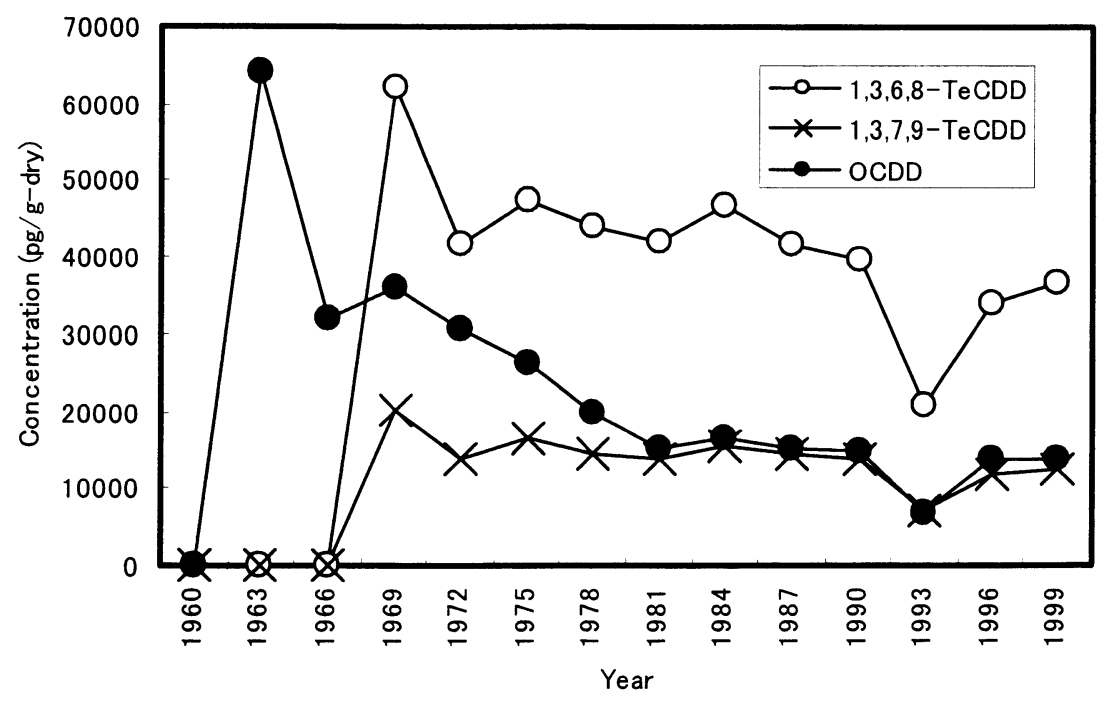

Fig. 8 Temporal change of OCDD, 1,3,6,8-and 1,3,7,9-TeCDD concentrations in paddy soils

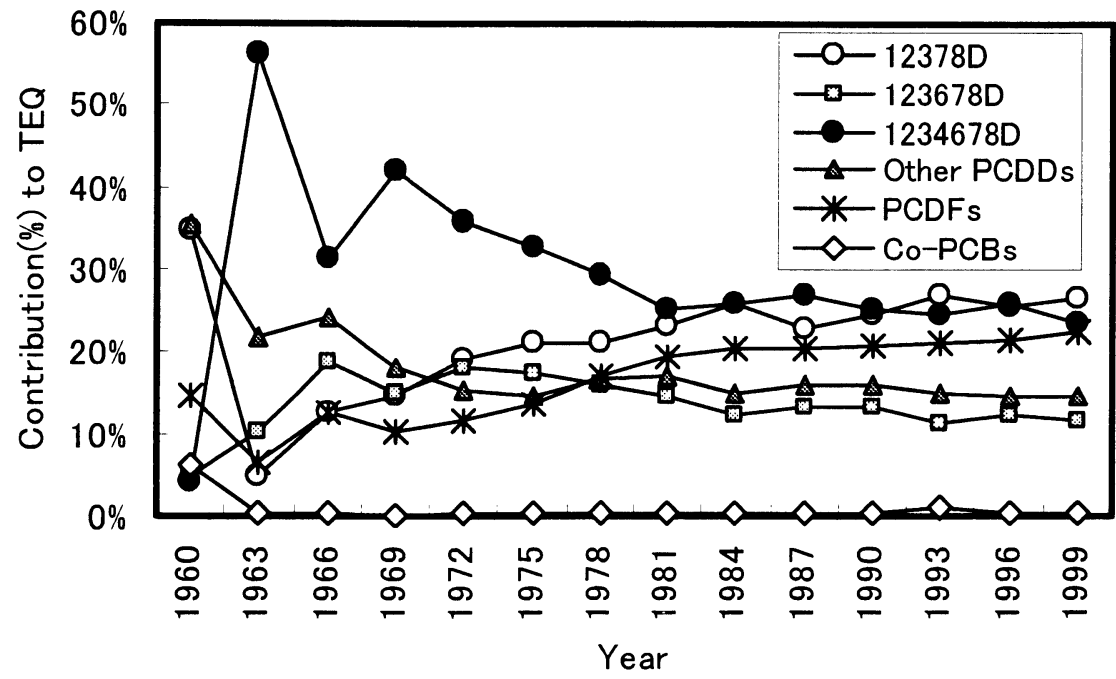

Fig. 9 Contribution (\%) to TEQ by 1,2,3,7,8-PeCDD, 1,2,3,6,7,8-HxCDD, 1,2,3,4,6,7,8-HpCDD, other PCDDs, PCDFs and Co-PCBs in paddy soils

2,3,7,8- 位塩素置換 PCDD/Fs の TEQへの寄与率が経時 的に変化していることを示している。すなわち，1960年 では PCP, CNP両製剤の影響が無いと考えられる非農 耕地土䁃とプロットが近く, 燃焼・焼却過程で生成され たと考えられる2,3,4,7,8-PeCDFといった PCDFsや 1,2,3,7,8-PeCDD といった異性体による寄与が高かっ た。1963年と1966年では1,2,3,4,6,7,8-HpCDD といっ た PCP 製剤中に含まれる異性体による寄与率が, 1969 年以降では $1,2,3,7,8-\mathrm{PeCDD}$ といった CNP 製剤中に含 まれる異性体による寄与率が高くなっていた。そして
1980年代以降は, Fig. 4 で示した PCP, CNP 両製剤に由 来する PCDD/Fs がそれ以前に比べ非常に少ないため, 2,3,7,8 - 位塩素置換 PCDD/Fs による寄与率の劇的な変 化はない。しかし，2,3,4,7,8-PeCDF といったPCDFs による寄与率が上昇しているため，そのプロットは1960 年に向かって推移している。Kjeller ら ${ }^{25)}$ は, イギリスの ローザムステッド農業試験場で1846年から1986年に保存 された農耕地土壤中ダイオキシン類を分析した。その結 果, この期間の主要な PCDD/Fs の起源は燃焼・焼却過程 であり，20世紀初期以降濃度が上昇していることを明ら 


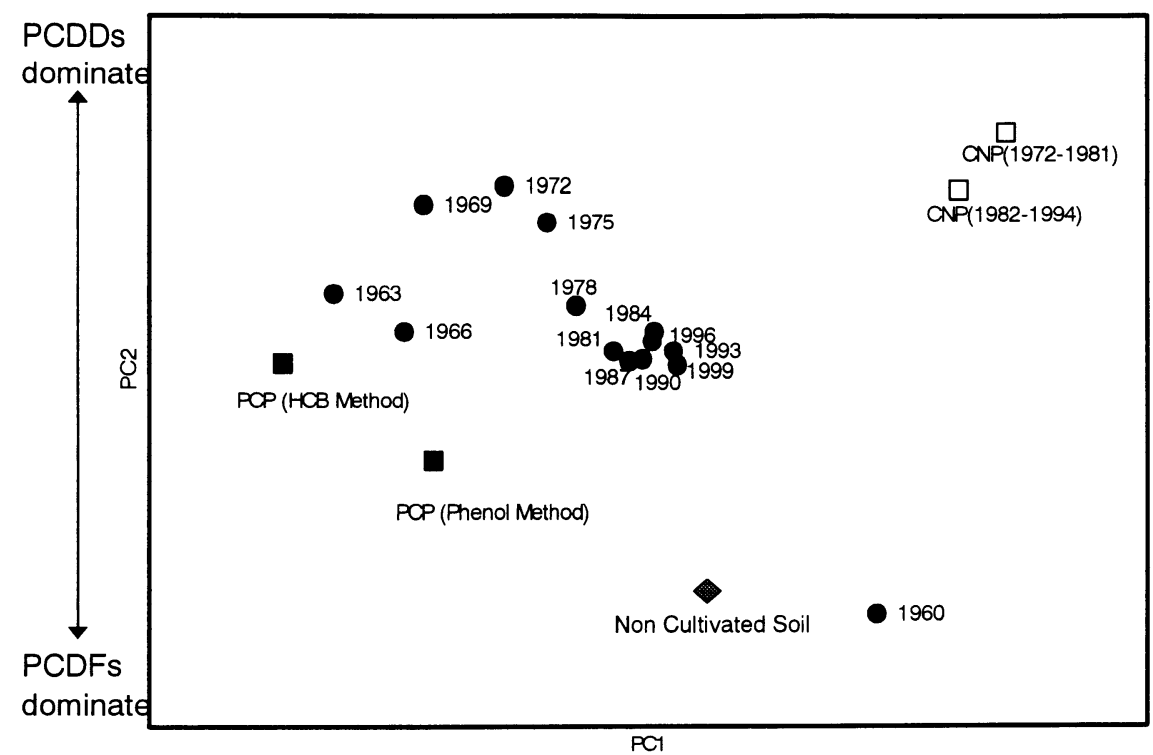

Fig. $10 \mathrm{PCA}$ Plot of contribution (\%) to TEQ by 2,3,7,8-substituted PCDD/Fs in paddy soils, PCP, CNP and non cultivated soils ${ }^{27}$

かにしている。これは，水田土壤においてもバックグラ ウンドとして, 燃焼・焼却過程で生成したPCDD/Fs の污 染があることを示している。これらのことから，近年， 特に1980年代以降, 水田土壤中の PCDD/Fs は燃焼・焼却 過程で生成したPCDD/Fs の大気沈着や流入といった $\mathrm{PCP}, \mathrm{CNP}$ 製剂以外の影響が増加していることが示唆さ れる。

\section{要 約}

PCP 及び CNP 製剤中のダイオキシン類を分析し，そ の濃度と組成を明らかにした。PCP 製剤では製造方法に よりダイオキシン類の濃度及び組成が異なることが示唆 された。また CNP 製剤中のダイオキシン類濃度は1982 年以降急激に濃度が減少していることが明らかとなっ た。両製剤に由来するダイオキシン類総量は，1960年代 前半はほとんどが PCP 製剤に由来するダイオキシン類 で占められ，1960年後半から CNP 製剤に由来するダイ オキシン類の割合が増加することが推察された。

また水田土壤中ダイオキシン類濃度および TEQ は, 60年代初期から上昇し, その後緩やかに減少しているこ とが分かった。濃度の推移に影響しているのはPCP, CNP製剤の使用であり，両製剤に主要に含まれる OCDD と1,3,6,8-TeCDD そして1,3,7,9-TeCDD といった異性 体から確認できた。しかし，2,3,7,8-位塩素置換 $\mathrm{PCDD} / \mathrm{Fs}$ の TEQへの寄与率について主成分分析により 解析したところ, PCP, CNP 製剤に由来するダイオキシ ン類だけではなく，燃焼・焼却過程で生成したダイオキ
シンといった両製剤以外の起源からの寄与割合が徐々に 増加していることが明らかとなった。

\section{文 献}

1) Hiraoka, M. and Okajima, S.: Source control technologies in MSW incineration plants. Organohalogen Compounds, 19, 275-291 (1994)

2) Wakimoto, T., Kannan, N., Ono, M., Tatsukawa, R. and Masuda, Y.: Isomer-specific determination of polychlorinated dibenzofurans in Japanease and American polychlorinated biphenyls. Chemosphere, 17, 743-50 (1988)

3) Kodavanti, P.R., Kannan, N., Yamashita, N., DerrYellin, E.C., Ward, T.R., Burgin, D.E., Tilson, H.A. and Birnbaum, L.S.: Differential effects of two lots of Arochlor1254; Congener-specific analysis and neurochemical end points. Environmental Health Perspectives, 109, 1153-1161 (2001)

4) Malisch, R.: Determination of PCDD/PCDF in PCB products and milk samples; correlation between PCB- and PCDD/PCDF-contamination of milk samples. Organohalogen Compounds, 20, 209214 (1994)

5) Buser, H. and Bosshardt, H.P.: Determination of 2, 3,7,8-tetrachlorodibenzo-1,4-dioxin at parts per billion levels in technical-grade 2,4,5-trichlorophenoxyacetic Acid, in 2,4,5-T alkyl ester and 2,4,5-T 
amino salt herbicide formulations by quadrupole mass fragmentography. J. Chromatography, 90, 7177 (1974)

6) Rappe, C.: Identification and quantification of polychlorinated dibenzo- $p$-dioxins (PCDDs) and dibenzofurans (PCDFs) in 2,4,5-T-ester formulations and herbicide orange. Chemosphere, 7, 431-438 (1978)

7) Cochrane, W.P., Singh, J.S., Miles, W. and Wakeford, B.: Determination of chlorinated dibenzo- $p$-dioxin contaminations in 2,4-D products by gas chromatography-mass spectrometric techniques. $J$. Chromatography, 217, 289-299 (1981)

8) Jensen, S. and Renberg, L.: Contaminants in pentachlorophenol; Chlorinated dioxins and predioxins. AMBIO, 1, 62-65 (1972)

9) Buser, H.R.: Polychlorinated dibenzo-p-dioxins seperation and identification of isomers by gas chromatography-mass spectrometry. J. Chromatography, 114, 95-108 (1975)

10) Hagenmainer, $H$. and Brunner, $H .:$ Isomerspecific analysis of pentachlorophenol and sodium pentachlorophenate for 2,3,7,8-substituted PCDD and PCDF at sub-ppb levels. Chemosphere, 16, 1759-1764 (1987)

11) Masunaga, S., Takasuga, T. and Nakanishi, J.: Dioxin and dioxin-like PCB impurities in some Japanese agrochemical formulations. Chemosphere, 44, 873-885 (2001)

12) Yamagishi, T., Miyazaki, T., Akiyama, K., Morita, M., Nakagawa, J., Hori, S. and Kaneko, S.: Polychlorinated dibenzo-p-dioxins and dibenzofurans in commercial diphenyl eater herbicides, and in freshwater fish collected from the application area. Chemosphere, 10, 1137-1144 (1981)

13）日本植物防疫協会：農薬要覧（1958-2000）

14）清家伸康, 松本めぐみ, 松田宗明, 河野公栄, 脇本 忠明：松山平野における底質中ダイオキシン類の分 布と挙動，環境化学，12，89-96（2002）

15）酒井伸一, 出口晋吾, 浦野真弥, 高月 紘, 恵和 子：琵琶湖および大阪湾底質中のダイオキシン類に 関する歴史トレンド解析，環境化学，9，379-390 (1999)

16) Masunaga, S., Yao, Y., Ogura, I., Nakai, S., Kanai, Y., Yamamuro, M. and Nakanishi, J.: Identifying sources and mass balance of dioxin pollution in lake Shinji basin, Japan. Environmental Science and Technology, 35, 1967-1973 (2001)

17）高菅卓三，阿部昌宏，井上 毅：ダイオキシン特定 異性体分離を目的としたアルミナカラムクロマトグ ラフィーの検討, pp252-253, 第 9 回環境化学討論 会講演要旨集 $(2000)$

18) Ryan, J.J., Conacher, H.B.S., Panopio, L.G., Lau, B.P.Y. and Hardy, J.A.: Gas chromatographic separations of all 136 tetra- to octa-polychlorinated dibenzo- $p$-dioxins and polychlorinated dibenzofurans on nine different stationary phases. J. Chromatography, 541, 131-183 (1991)

19）農林水産省：農薬に含まれるダイオキシン類の調査 結果について，2002年 4 月

20) Van den Berg, M., Birnbaum, L., Bosveld, A.T.C., Brunstrom, B., Cook, P., Feeley, M., Giesy, J.P., Hanberg, A., Hasegawa, R., Kennedy, S.W., Kubiak, T., Larsen, J.C., Rolaf van Leeuwen, F.X., Djien Liem, A.K., Nolt, C., Peterson, R.E., Poellinger, L., Safe, S., Schrenk, D., Tillitt, D., Tysklind, M., M Younes, M., Warn, F. and Zacharewski, T.: Toxic equivalency factors (TEFs) for PCBs, PCDDs, PCDFs for humans and wildlife. Environmental Health Perspectives, 106, 775-792 (1998)

21）脇本忠明：農用地土壤におけるダイオキシン類の分 布と動態，pp15-19，第23回環境化学講演会（1998）

22）日本統計協会：日本長期統計総覧

23）環境庁：ダイオキシン類に係る土壌調査測定マニュ アル，2000年 1 月

24）環境省・農林水産省：平成12年度農用地土壤および 農作物に係るダイオキシン類実態調査結果, 2001年 8 月

25) Kjeller, L.-O., Jones, K.C., Johnston, A.E. and Rappe, C.: Increases in the Polychlorinated dibenzo$p$-dioxin and -furan content of soils and vegetation since the 1840s. Environ. Sci. Technol., 25, 16191627 (1991)

26) Alcok, R.E., Mclachlan, M.S., Johnston, A.E. and Jones, K.C.: Evidence for the presence of $\mathrm{PCDD} / \mathrm{Fs}$ in the environment prior to 1900 and further studies on their temporal trends. Environ. Sci. Technol., 32, 1580-15877 (1998)

27）環境庁：ダイオキシン類緊急一斉調査結果について (平成10年度実施)，1999年 9 月 